DOI: 10.32089/WBH.PHW.2020.4(274).0002

orcid.org/0000-0002-2518-1376

\author{
Kamil AnduŁa
}

(Uniwersytet Mikołaja Kopernika;

Wojskowe Biuro Historyczne im. gen. broni Kazimierza Sosnkowskiego)

\title{
Bitwa w Pradolinie Redy-Łeby. Działania bojowe sowieckich wojsk pancernych na kierunku Gdyni (6-16 marca 1945 r.) ${ }^{1}$
}

Działania wojenne na Pomorzu Gdańskim, prowadzone w 1945 r., rzadko były przedmiotem pogłębionej analizy w polskiej historiografii wojskowej ${ }^{2}$. Przed 1989 r. całokształt opisu działań wojennych na ziemiach polskich leżał w gestii historyków Wojskowego Instytutu Historycznego im. Wandy Wasilewskiej, którzy przenieśli na polski grunt sowiecką optykę i wzorowali się na opisach działań bojowych Armii Czerwonej. Tymczasem sowiecka historiografia wojskowa cechowała się dominacją studiów o charakterze strategiczno-operacyjnym nad innymi rodzajami narracji ${ }^{3}$ Z tego powodu

\footnotetext{
${ }^{1}$ Fragmenty artykułu zostały opublikowane w popularnonaukowym czasopiśmie „Wojsko i Technika. Historia”, zob. K. Anduła, Kaszubska pułapka, pancerne boje pod Sławnem, Stupskiem, Lęborkiem i Wejherowem, cz. 1, „Wojsko i Technika. Historia” 2019, nr 1, s. 50-63; cz. 2, „Wojsko i Technika. Historia” 2019, nr 2, s. 52-68.

${ }^{2}$ Literaturę przedmiotu scharakteryzował Mariusz Kardas, zaznaczając, że: „Najsłabiej opracowanym okresem historycznym II wojny światowej w dziejach wybrzeża gdańskiego jest schyłek okupacji hitlerowskiej”. Zob. M. Kardas, Wybrzeże gdańskie jako pole bitwy w 1945 roku. Na obrzeżach działań wojennych frontu wschodniego [w:] Kresy, granice i pogranicza w historii wojskowej, red. A. Olejko, Oświęcim 2014, s. 364 . W ostatnich latach problematykę walk na Pomorzu Gdańskim podjął Tomasz Gliniecki, zob. T. Gliniecki, D. Panto, Krzywy obraz wojny. Armia Czerwona w Gdańsku i Prusach w 1945 r., Gdańsk 2019, passim; T. Gliniecki, Walki Armii Czerwonej w delcie Wisly (styczeń-maj 1945), Gdynia-Sztutowo 2019, passim; idem, Echa pancernego rajdu. Propaganda wojenna i mity wyzwoleńcze na przykładzie operacji mławsko-elbląskiej Armii Czerwonej w 1945 roku, Gdańsk 2017, passim.

${ }^{3}$ Współczesna rosyjska historiografia wojskowa ocenia walki na Pomorzu Gdańskim z większą dozą krytycyzmu, lecz unika jednoznacznych stwierdzeń, które wpłynęłyby
} 
badania cząstkowe nad bitwami i potyczkami, składającymi się na ogół działań zbrojnych na Pomorzu Gdańskim, stanowią marginalną część dorobku rodzimej historiografii. Potwierdzeniem tego jest historiografia dotycząca bitwy w Pradolinie Redy-Łeby. Ze względu na przebieg i szczególne uwarunkowania geograficzne bitwa ta daje się wyodrębnić z całości działań bojowych na Pomorzu Gdańskim, a jej przebieg dostarcza wielu ciekawych wniosków, przedstawionych w niniejszym tekście.

Pradolina Redy-Łeby położona jest we wschodniej części Pobrzeża Koszalińskiego. Ma około $90 \mathrm{~km}$ długości i $353 \mathrm{~km}^{2}$ powierzchni, przy czym rozszerza się w kierunku zachodnim i południowo-zachodnim od 1,2 km w okolicy Wejherowa do 5,5 km u wylotu na Wybrzeże Słowińskie. U podnóża pradoliny płyną dwie rzeki: Łeba, która uchodzi na północny zachód do jeziora Łebsko, oraz Reda z ujściem do Zatoki Gdańskiej. Dział wodny obu rzek leży pod Strzebielinem na wysokości 40 m n.p.m. Przez obszar pradoliny przebiega szosa i linia kolejowa łącząca Gdynię z Koszalinem i Szczecinem. Znajdują się tu miasta: Lębork, Wejherowo, Reda i Rumia. Teren po obu stronach drogi jest torfiasty i poprzecinany kanałami melioracyjnymi, co w znacznym stopniu utrudnia rozwinięcie wojsk szybkich w polu. Opisując morfologię terenu Pradoliny Redy-Łeby, należy zauważyć, że na północ od pradoliny górują strome, lesiste wzgórza Wysoczyzny Żarnowieckiej, na południe zaś rozciąga się silnie pofałdowany obszar Pojezierza Kaszubskiego. Wylot Pradoliny w kierunku Bałtyku zamykają trudne do pokonania Mostowe Błota i bagnisty teren Białej Rzeki. Łąki o torfiastym, mokrym podłożu ciągną się od Rumi przez Chylonię do portu gdyńskiego. Pas ten, dodatkowo poprzecinany licznymi strumieniami, otacza Kępę Oksywską i broni dostępu do Gdynit. Mimo że jest to najwyraźniejsza na Pobrzeżach Południowobałtyckich pradolina, to nie jest jedyna. Obecność pradolin i form pradolinopodobnych jest cechą charakterystyczną polodowcowego krajobrazu Pomorza Gdańskiego, co powoduje rozcięcie wysoczyzn tej części pobrzeża na szereg izolowanych od siebie płatów, tworząc charakterystyczny krajobraz kępowy . Wymienione cechy szczególne terenu odcisnęły piętno na przebiegu walk obronnych toczonych w 1939 r. (obrona Kępy Oksywskiej) i nie pozostały bez wpływu na trwałość niemieckiej obrony w marcu $1945 \mathrm{r}$.

negatywnie na wizerunek Armii Czerwonej. Zob. Великая Отечественная война 1941-1945 годов в двенадияати томах, t. 5: Победный финал. Завершающие операции Великой Отечественной войны в Европе. Война с Японией, red. Г. Н. Севостьянов, Москва 2013, s. 283; Historia wielkiej wojny narodowej Zwiazku Radzieckiego 1941-1945 w 6 tomach, t. 5: Zwycięskie zakończenie wojny z hitlerowskimi Niemcami. Klęska imperialistycznej Japonii (1945 r.), red. S. I. Roszczin, tłum. J. Nowacki, Warszawa 1965, s. 167-168.

${ }^{4}$ Słownik geograficzno-krajoznawczy Polski, red. M. I. Mileska, Warszawa 1998, s. 666.

${ }^{5}$ A. A. Marsz, Główne cechy geomorfologiczne [w:] Pobrzeże Pomorskie, red. B. Augustowski, Wrocław-Warszawa 1984, s. 51. 
Rozpoczęta 12 stycznia 1945 r. operacja wiślańsko-odrzańska Armii Czerwonej doprowadziła do utworzenia przyczółków na Odrze, które bezpośrednio zagrażały Berlinowi, jednak zdobycie stolicy III Rzeszy było niemożliwe bez zniszczenia silnego zgrupowania wojsk niemieckich na Pomorzu. W pierwszych dniach marca 1945 r. obszaru Pomorza od Odry do Trójmiasta broniły niemieckie armie 11 i 2 ze składu Grupy Armii (GA) "Wisła”. Linia rozgraniczenia między armiami przebiegała następująco: Szczecinek-Białogard-Kołobrzeg. Ofensywa skierowana przeciwko siłom niemieckim na Pomorzu Gdańskim prowadzona była od 8 lutego 1945 r. przez siły 1 i 2 Frontu Białoruskiego (F. Biał.), lecz nie przyniosła rozstrzygnięcia na korzyść Sowietów. Decydująca dla przebiegu operacji pomorskiej okazała się decyzja marsz. Gieorgija Żukowa, dowódcy 1 F. Biał., o przegrupowaniu znad Odry na Pomorze Zachodnie dwóch gwardyjskich armii pancernych (1 i 2), które podjęły działania zaczepne w kierunku Morza Bałtyckiego. 1 Armia Pancerna Gwardii (APanc. Gw.) liczyła 35470 oficerów i żołnierzy w jednostkach bojowych, 419 czołgów, 143 działa pancerne, 514 dział i moździerzy i 39 wyrzutni rakiet ${ }^{6}$. Jej uderzenie na kierunku kołobrzeskim zaczęło się 1 marca 1945 r. Po pięciu dniach sowieckie czołgi osiągnęły brzeg Morza Bałtyckiego w rejonie Kołobrzegu, kończąc tym samym ważny etap operacji pomorskiej. Efektem tego etapu operacji było rozdzielenie zgrupowania niemieckiego na dwie odseparowane od siebie części. Pobite oddziały 11 Armii (A) wycofały się w kierunku Odry przez obszar Pomorza Zachodniego, zaś 2 A została odcięta od reszty sił niemieckich na Pomorzu Gdańskim.

Kolejnym etapem operacji pomorskiej miało być zniszczenie wojsk niemieckich, broniących się na Pomorzu Gdańskim. Zadanie zlikwidowania niemieckiej 2 A w rejonie Gdańska i Gdyni otrzymał 2 F. Biał., dowodzony przez marsz. Konstantego Rokossowskiego. W skład 2 F. Biał. wchodziły: 2 Armia Uderzeniowa, 65, 49, 70 i 19 A, a także 3 Korpus Pancerny Gwardii (KPanc. Gw.) i 3 Korpus Kawalerii Gwardii. Wsparcie z powietrza zapewniała 4 Armia Lotnicza 7.

Mimo że plan zdobycia Berlina powstał w lutym 1945 r., to kierownictwo Najwyższego Naczelnego Dowództwa (Stawki) Związku Sowieckiego uzależniło termin rozpoczęcia operacji berlińskiej od zniszczenia wojsk niemieckich na Pomorzu. Dopiero spełnienie tego warunku pozwalało na zaangażowanie całości sił $2 \mathrm{~F}$. Biał. w planowaną ofensywę. Aby przyśpieszyć realizację tego zadania, Stawka zgodziła się oddać pod rozkazy marsz. Rokossowskiego całą 1 APanc. Gw., która dopiero co zakończyła działania ofensywne w rejonie

\footnotetext{
${ }^{6}$ Центральный Архив Министерства Обороны Российской Федерации (dalej: ЦАМO), fond (dalej: f.) 299: 1 гвардейская танковая армия (dalej: f. 299), opis (dalej: о.) 3070, delo (dalej: d.) 759, Доклад о боевых действиях 1 гв. ТА, b.m. 23 V 1945 r., s. 6.

${ }^{7}$ Боевой состав Советской Армии, сz. V: (январь-сентябрь 1945 года), red. М. А. Гареев, Москва 1990, s. 82-83.
} 
Koszalina i Kołobrzegu ${ }^{8}$. Po zniszczeniu wojsk niemieckich na Pomorzu Gdańskim armia miała powrócić pod rozkazy dowódcy 1 F. Biał. Podczas rozmowy telefonicznej marsz. Żukow podał marsz. Rokossowskiemu informacje o stanie pododdziałów, nadmieniając przy tym, że: „Armia powinna być zwrócona dokładnie w takim stanie, w jakim została przekazana" Natychmiastowe wprowadzenie do walki 1 APanc. Gw. okazało się niemożliwe z powodów logistycznych. Służby i składy zaopatrzenia znajdowały się w okolicach Recza - $120 \mathrm{~km}$ od aktualnej dyslokacji jednostek i potrzeba było kilku dni na podciągnięcie ich w rejon Koszalina ${ }^{10}$. W pododdziałach czas ten wykorzystano na odpoczynek i naprawy sprzętu po intensywnych walkach o Białogard i Kołobrzeg ${ }^{11}$.

Zgodnie z dyrektywą Stawki z 5 marca marsz. Rokossowski postanowił wykonać główne uderzenie siłami lewego skrzydła frontu wzdłuż Pradoliny Redy-Łeby ${ }^{12}$. Natarcie miało przebiegać po osi: Sławno-Słupsk-Lębork-Wejherowo, a następnie w dwóch kierunkach: na Puck oraz przez Redę i Rumię do Gdyni. Zdobycie strategicznie ważnego portu w Gdyni miało skutkować załamaniem niemieckiej obrony na Pomorzu Gdańskim. Za wyborem wyżej opisanej osi natarcia przemawiał fakt, że pod Koszalinem ześrodkowała się stosunkowo silna 19 A, dowodzona przez gen. por. Władimira Romanowskiego. Armia ta została oddana $\mathrm{z}$ odwodu Stawki na początku lutego, nie uczestniczyła jeszcze w walkach, które poważnie uszczupliłyby jej potencjał. Na tyłach 19 A znajdowała się już 1 APanc. Gw., a także 3 KPanc. Gw. - taka dyslokacja sił i środków umożliwiała podjęcie skutecznej ofensywy bez zbędnych przegrupowań.

Obszar Równiny Słupskiej, na którym miały się toczyć walki w dniach od 6 do 10 marca, sprzyjał rozwinięciu wojsk szybkich. Do dzisiaj jest to kraina o typowo rolniczym krajobrazie. Pod względem morfologicznym dominuje tu teren lekko falisty lub zupełnie płaski. Przeciętna wysokość waha się w przedziale od 20 do $30 \mathrm{~m}$ n.p.m. Występują tu łęgi i zagajniki, sprzyjające organizacji zasadzek. Potencjalną przeszkodę dla nacierających

${ }^{8}$ № 310, Директива Ставки ВГК № 11034 командующим войсками 1-го и 2-го белорусских фронтов о временном переподчинении 1-й гв. Танковой армии [w:] Русский архив: Великая Отечественная. Ставка ВКГ: Документы и материалы 1944-1945 (dalej: Русский архив), t. 16 (5-4), red. В. А. Золотарев, Москва 1999, s. 206.

${ }^{9}$ K. Rokossowski, Żołnierski obowiązek, tłum. F. Czuchrowski, Warszawa 1979, s. 384.

${ }^{10}$ W. Bieszanow, 1945 - rok zwycięstwa, tłum. G. Palacz, A. Palacz, Warszawa 2013, s. 214.

${ }^{11}$ Zob. K. Anduła, Działania bojowe jednostek Armii Czerwonej w bitwie o Kołobrzeg (4-18 marca 1945 r.), „Meritum” 2018, t. X, s. 219-237; idem, Pancerne preludium. 45. Brygada Pancerna Gwardii w bitwie o Kołobrzeg 4-7 marca 1945 roku, „Technika Wojskowa: Historia” 2017, nr 7, s. 62-72.

${ }^{12}$ № 310, Директива Ставки ВГК № 11034..., s. 206. 
wojsk stanowią płynące południkowo rzeki Wieprza, Słupia, Łupawa, Łeba, Okalica i Reda, a także Kanał Łebski. Ich brzegi nie są strome, ale bywają podmokłe, zwłaszcza w okresie wiosennego przyboru wód. Dodatkowo istniejący system śluz i zapór umożliwia spiętrzenie wody, co znacząco podwyższa walory obronne terenu. Owo zagrożenie, wynikające z ukształtowania terenu, dostrzegał dowódca 2 F. Biał. 8 marca marsz. Rokossowski przeprowadził rozmowę z gen. Michaiłem Katukowem na temat wykorzystania dowodzonej przezeń 1 APanc. Gw. na Pomorzu Gdańskim, podczas której wyraził obawę co do ewentualności napotkania oporu wojsk niemieckich na odcinku rzeki Łupawy, wskazując, że „rzeka może odegrać fatalną rolę w dalszym biegu wydarzeń. Niemcy odejdą za nią, umocnią się, oprą się plecami o Morze Bałtyckie i będziemy musieli przelać niemało krwi, zanim uda się ich zlikwidować"13.

$\mathrm{Na}$ podstawie poczynionej oceny sytuacji marsz. Rokossowski postawił dowództwu 1 APanc. Gw. cele operacyjne. Zadanie bliższe armii miało polegać na wyjściu na linię rzeki Łupawy, a następnie rzeki Łeby wraz z uchwyceniem przepraw na tych przeszkodach wodnych. Zadanie dalsze określono w rozkazie dowództwa armii nr 0016/op z 9 marca: „Armia od jutra 10 marca głównymi siłami z rubieży ŁUPAWA, GŁÓWCZYCE wyprowadzi uderzenie $\mathrm{w}$ kierunku WEJHEROWO z zadaniem niedopuszczenia do zajęcia przez nieprzyjaciela dogodnej rubieży i do końca dnia 11.3 .45 roku wyjdzie nad brzeg zatoki gdańskiej na odcinku GDYNIA, PUCK”"14.

Problemem dla marsz. Rokossowskiego było to, że 6 marca - w dniu rozpoczęcia działań zaczepnych na gdyńskim kierunku operacyjnym 19 A mogła wprowadzić do boju tylko dwa z trzech korpusów: 40 Korpus Strzelecki Gwardii (KSGw.) w składzie: 10, 101, 102 Dywizja Strzelecka Gwardii (DSGw.), które nacierały z rejonu Polanowa i Miastka w kierunku Lęborka, i 132 KS (18, 27, 313 DS), przemieszczający się wzdłuż wybrzeży Bałtyku. Trzeci korpus - 134 KS (205, 272, 310 DS) - był skierowany frontem na południowy zachód i zabezpieczał lewe skrzydło armii, zwalczając oddziały niemieckie wycofujące się w kierunku Kołobrzegu. Biorąc pod uwagę dotychczasową praktykę działań Armii Czerwonej, była to siła niewystarczająca. W związku z powyższym, przed wprowadzeniem 1 APanc. Gw., zadanie rozbicia niemieckiej obrony na kierunku słupskim otrzymał 3 KPanc. Gw.

3 KPanc. Gw. dowodził gen. por. Aleksy Panfiłow. W skład korpusu wchodziły: dowództwo i sztab, 3, 18, 19 Brygady Pancerne Gwardii (BPanc.

${ }^{13}$ M. Katukow, Pancerny grot, tłum. J. Żarek, Warszawa 1976, s. 408.

${ }^{14}$ Podano polskie nazwy geograficzne w miejsce niemieckich, którymi posługiwał się autor dokumentu; ЦАМО, f. 299, о. 3070, d. 827, Журнал боевых действий 1 гв. ТА, b.m. 30 V 1945 r., k. 116. Tłumaczenia z rosyjskiego, jeżeli nie zaznaczono inaczej, pochodzą od autora. 
Gw.), 2 Brygada Zmotoryzowana Gwardii (BZmot. Gw.), 430 Batalion Łączności, 154 Batalion Saperów, 218 Kompania Obrony Przeciwchemicznej, 7 Kompania Dowozu Materiałów Pędnych i Smarów Gw., 114 Polowa Baza Remontu Samochodów, 74 Polowa Baza Remontu Czołgów, 266 Klucz Samolotów Łącznikowych, 43 Piekarnia Polowa, 418 Kasa Banku Polowego, 2106 Poczta Polowa. Ponadto dowództwu 3 KPanc. Gw. podporządkowano szereg jednostek wsparcia: 2 Brygadę Motocyklową Gwardii (BMot. Gw.), 375 Pułk Ciężkiej Artylerii Pancernej Gwardii, 1436 i 1496 Pułki Artylerii Pancernej (papanc.), 421 Pułk Artylerii Haubic, 1072 Pułk Artylerii Lekkiej, 266 Pułk Moździerzy, 1701 i 1984 Pułki Artylerii Przeciwlotniczej, 10 Batalion Motocyklowy Gw., 324 Dywizjon Rakietowy Gw. W dniu 25 lutego 1945 r. 3 KPanc. Gw. wraz z jednostkami wzmocnienia dysponował: 174 czołgami T-34-85, 63 działami pancernymi (21 SU-76M, 21 SU-100, 21 ISU-122), 40 samochodami pancernymi, 108 armatami i haubicami, 123 moździerzami, 69 armatami plot. i karabinami maszynowymi oraz 8 wyrzutniami rakiet ${ }^{15}$.

Przed 2 F. Biał. broniła się niemiecka 2 A, dowodzona do 9 marca przez gen. płk. Waltera Weissa, a od 10 marca przez gen. wojsk panc. (General der Panzertruppe) Dietricha von Sauckena. Wraz z wyjściem Sowietów nad Bałtyk pod Koszalinem i Kołobrzegiem $2 \mathrm{~A}^{16}$ znalazła się w kotle obejmującym niemal cały obszar Pomorza Gdańskiego. Położenie operacyjne skomplikowało się tym bardziej, że wojska 2 A walczyły frontem na południe, a wyjście Sowietów pod Koszalin stwarzało zagrożenie od zachodu. Jedyne siły zdolne do stawienia oporu przeciwnikowi, nacierającemu od strony Koszalina, podporządkowane były dowództwu VII KPanc. ${ }^{17}$, którym dowodził gen. wojsk panc. Mortimer von Kessel. W skład tego korpusu wchodziły:

${ }^{15}$ W dniach 25 II - 4 III 1945 r. 3 KPanc. Gw. poniósł straty w postaci: 17 zniszczonych i 19 uszkodzonych T-34-85 oraz 3 spalonych SU-100 i jednego SU-76M. Część uszkodzonych czołgów udało się wyremontować do czasu rozpoczęcia nowych walk. Ponadto 19 A dysponowała wsparciem w postaci 108, 1525, 1531 papanc. Każdy z pułków powinien liczyć zgodnie z etatem 21 dział pancernych SU-76M. Tym samym Armia Czerwona mogła zgromadzić na gdyńskim kierunku operacyjnym około 260 czołgów. ЦАМO, f. 3401: 3 гвардейский танковый корпус (dalej: f. 3401), o. 1, d. 38, Журнал боевых действий 3 гв. тк, b.m. 1 V 1945 r., k. 1, 11-16.

${ }^{16}$ Początkowo 2 A wchodziła w skład GA „Wisła”, jednak w związku z odcięciem jej sił od reszty GA 11 III 1945 r. podporządkowano ją dowództwu GA „Północ”.

${ }^{17}$ Ponadto w Lęborku znajdowała się część sztabu LV Korpusu Armijnego (KA), którego jednostki walczyły w Prusach Wschodnich. Sztab korpusu pełnił jedynie funkcje administracyjne. Podlegały mu jednostki tyłowe i zapasowe pozostałe po 549 Dywizji Grenadierów Ludowych (której żołnierze w większości zostali dyslokowani pod Szczecin), jednostki alarmowe i artylerii przeciwlotniczej w Ustce, 5 Zapasowy Dywizjon Kawalerii w Słupsku, oddział (szczegółów nie ustalono) niszczycieli czołgów „Emil”, pułk kolejowy oraz pododdziały Volkssturmu. Linia rozgraniczenia między LV KA a VII KPanc. przebiegała przez Korzybie-Janiewice-Podgórki; K.-H. Pagel, Der Landkreis Stolp in Pommern. Zeugnisse seiner deutschen Vergangenheit, Lübeck 1989, s. 306. 
32 Dywizja Piechoty (DP), 7 Dywizja Pancerna (DPanc.), 4 Policyjna Dywizja Grenadierów Pancernych SS (PDGPanc. SS), 226 Brygada Dział Szturmowych (BDzSzt.), Dywizjon Rozpoznawczy „München”18 oraz 743 Dywizjon Niszczycieli Czołgów (dncz) i częściowo rozbity 424 batalion niszczycieli czołgów (bncz) $)^{19}$.

Od końca lutego VII KPanc. związany był ciężkimi walkami na swym lewym skrzydle, tym samym jego prawe skrzydło (oparte na wybrzeżu Bałtyku) pozbawione było znaczących sił. Odcinek frontu od Darłowa do Sławna broniony był przez 7 Pułk Grenadierów Pancernych SS (pgpanc. SS) z 4 PDGPanc. SS, wsparty oddziałem saperów i jednym batalionem Volkssturmu. Na południe od Sławna front stał otworem na odcinku $15 \mathrm{~km}$ - wzdłuż lesistych brzegów rzeki Wieprzy. W rejonie wsi Barwino i Barcino bronił się Dywizjon Rozpoznawczy „München”. Dalej na południe od Barcina, na odcinku $12 \mathrm{~km}$ rozciągały się gęste lasy, dopiero w rejonie wsi Płocko i Przytocko - $10 \mathrm{~km}$ na wschód od Polanowa - dozorował front jeden batalion 4 PDGPanc. SS. Reszta tej dywizji znajdowała się na odcinku pomiędzy wsią Świerzenko a Miastkiem. W walki w tym rejonie zaangażowana była także cała 7 DPanc. wraz z 743 dncz i 424 bncz. Linie obrony wymienionych oddziałów ciągnęły się do okolic wsi Pietrzykowo. Na lewym skrzydle VII KPanc walczyły 32 DP i 226 BDzSzt., utrzymując $13 \mathrm{~km}$ odcinek od Brzeźna Szlacheckiego do Lipnicy, tym samym blokując drogę na Bytów od południa. Sztab VII KPanc. znajdował się w Zielnie. Łącznie odcinek obrony VII KPanc. liczył 115 km długości, co oznaczało, że na jedną dywizję przypadało $38 \mathrm{~km}$ do obrony. Sytuację VII KPanc. pogarszał fakt, że w wyniku prowadzonych walk większość sił skupiona była na lewym - południowym - skrzydle frontu, gdzie liczne lasy i jeziora pozwalały skutecznie powstrzymywać natarcia Armii Czerwonej. Tymczasem nowe zagrożenie nadchodziło od zachodu, gdzie nie było jednostek zdolnych powstrzymać napór wojsk sowieckich, a teren na głębokości $70 \mathrm{~km}$ sprzyjał natarciu wojsk szybkich ${ }^{20}$.

${ }^{18}$ Według Martina Blocka jednostka została sformowana pod koniec stycznia 1945 r. na potrzeby organizującej się 104 Brygady Niszczycieli Czołgów. W związku z sytuacją na froncie trafiła w podporządkowanie VII KPanc. 11 III 1945 r. dywizjon został rozwiązany, a jego żołnierze i sprzęt posłużyły do uzupełnienia 4 dywizjonu rozpoznawczego 4 DPanc. https://forum.axishistory.com/viewtopic.php?t=89403 (dostęp 1 XII 2018 r.).

${ }^{19}$ Ponadto dowództwu VII KPanc. podlegały: 446 Brygada Budowlana (cztery bataliony Volkssturmu), 42 Brygada Saperów Szturmowych (tylko sztab i dowództwo bez dwóch batalionów), 748 Batalion Saperów, sztab 4 Pułku Saperów (bez żadnych jednostek w podporządkowaniu). ЦАМO, f. 500: Трофейный фонд (dalej: f. 500), o. 12467, d. 20, Lagekarte der Heeresgruppe „Weichsel”, b.m. 6 III 1945 r., k. 1.

${ }^{20}$ Należy zaznaczyć, że mobilność oddziałów pancernych niemieckiej 2 A została radykalnie ograniczona na skutek niedoboru materiałów pędnych. Kolejną przeszkodę stanowiły kolumny uciekinierów poruszające się w kierunku Gdańska i Gdyni; E. Murawski, Bój o Pomorze: ostatnie walki obronne na wschodzie, Oświęcim 2017, s. 207. 
Według oceny dowództwa 2 F. Biał. przed frontem 19 A siły nieprzyjaciela liczyły do 12 batalionów piechoty, wspieranych przez 4-5 baterii artylerii o łącznej sile do 14-15 luf oraz 2-5 baterii moździerzy. Wywiad sowiecki przecenił nieco siłę VII KPanc. szacując, że posiada 60 czołgów i 50 dział pancernych ${ }^{21}$. Faktyczne siły VII KPanc., przedstawiały się w następujący sposób: 8 marca 4 PDGPanc. SS dysponowała czołgiem dowodzenia, 14 sprawnymi działami szturmowymi StuG III lub IV oraz 17 armatami przeciwpancernymi (ppanc.) kal. $75 \mathrm{~mm}$. Stan osobowy dywizji na dzień 9 marca wynosił 4767 ludzi, z czego w linii znajdowało się 2744 oficerów i żołnierzy ${ }^{22} .7$ DPanc. posiadała czołg dowodzenia, dwa czołgi PzKpfw V Panther i 15 dział szturmowych StuG III lub IV, a ponadto 11 armat ppanc. kal. $75 \mathrm{~mm}^{23}$. Według danych z 9 marca 7 DPanc. liczyła 11832 ludzi $^{24}$, z czego w linii walczyło 3639 oficerów i żołnierzy. 743 dncz liczył 28 niszczycieli czołgów Jagdpanzer 38(t) Hetzer i był podporządkowany dowództwu 7 DPanc. 226 BDzSzt. miała 27 StuG III lub IV. 32 DP w toku walk straciła wszystkie działa szturmowe i armaty ppanc., jakie posiadała przed przybyciem na Pomorze ${ }^{25}$, a jej skład osobowy liczył prawdopodobnie 3,2 tys. ludzi, z czego w linii walczyło mniej niż 2,5 tys. oficerów i żołnierzy ${ }^{26}$. Łącznie VII KPanc. dysponował 4 czołgami i 84 działami pancernymi oraz 28 armatami ppanc.

W okresie od 6 do 11 marca stosunek sił w broni pancernej, na gdyńskim kierunku operacyjnym, pomiędzy jednostkami sowieckimi a niemieckimi, wynosił 3:1.

Po południu 5 marca wojska 2 F. Biał. przystąpiły do natarcia w kierunku Trójmiasta. Na froncie o szerokości $55 \mathrm{~km}$ od Trzebielina do wybrzeża Morza Bałtyckiego działania zaczepne prowadziła 19 A. Ze względu na kierunek natarcia i ukształtowanie sieci dróg w tej części Pomorza, naturalną osią natarcia stała się szosa: Koszalin-Sławno-Słupsk-Lębork-Wejherowo-Reda. Marszałek Rokossowski uważał Słupsk za ważny ośrodek przemysłowy

${ }^{21}$ ЦАМО, f. 46: Полевое управление 2-го Белорусского фронта (dalej: f. 46), о. 2394, d. 1186, Краткая сводка обобщенного боевого опыта войск 19 A, b.m. 14 IV 1945 r., k. 77 .

22 S. Hamilton, The Oder Front 1945, t. 2, Solihull 2014, s. 276.

${ }^{23}$ ЦАМО, f. 500, o. 12467, d. 25, Lagekarte der Heeresgruppe „Weichsel”, b.m. 8 III 1945 r., k. 1 .

${ }^{24}$ S. Hamilton, The Oder Front..., s. 247.

${ }^{25}$ ЦАМО, f. 500, o. 12467, d. 20, Lagekarte der Heeresgruppe „Weichsel”, b.m. 6 III 1945 r., k. 1 .

${ }^{26}$ Stan 32 DP podany według szacunków sowieckiego wywiadu wojskowego. Według tego samego źródła stan 4 PDGPanc. SS wynosił 4,5 tys. ludzi, z czego w lionii 3,6 tys., zaś 7 DPanc. 4 tys. ludzi, z czego w linii walczyło 3,2 tys. ЦАМO, f. 299, о. 3070, d. 743, Доклад о боевых действиях 1 гв. ТА, b.m. 23 V 1945 r., k. 26. 
III Rzeszy. Wiedząc, że przebiega tędy linia ufortyfikowana Wału Pomorskiego (umocnienia skierowane były frontem na wschód), dowódca 2 F. Biał. podejrzewał, że miasto będzie silnie bronione. Nie chcąc dopuścić do spadku tempa natarcia, które i tak uznał za niedostateczne, postanowił powierzyć zadanie zdobycia Słupska gen. Panfiłowowi - dowódcy 3 KPanc. Gw. ${ }^{27}$ Po opanowaniu przez 3 KPanc. Gw. i 19 A linii Kobylnica-Słupsk-Ustka marsz. Rokossowski planował wprowadzić do bitwy 1 APanc. Gw. ${ }^{28}$

Walki na przedpolach Sławna rozpoczęły się nocą z 5 na 6 marca 1945 r. za sprawą natarcia pododdziałów $132 \mathrm{KS}^{29}$. Jednostki $3 \mathrm{KPanc}$. Gw. dotarły $\mathrm{w}$ rejon miasta dopiero po zachodzie słońca, przez co nie wzięły udziału w tym boju. Do działań zaczepnych 3 KPanc. Gw. przystąpił 6 marca 1945 r. o godz. $14.00^{30}$. Pojawienie się tej dużej jednostki pancernej stało się dla obrońców asumptem do natychmiastowego odwrotu na zachód ${ }^{31}$. Rankiem 7 marca żołnierze 27 DS zajęli opuszczone Sławno ${ }^{32}$, zaś 3 KPanc. Gw. wyruszył w kierunku Słupska ${ }^{33}$. Podobnie jak to miało miejsce w przypadku Sławna, dowództwo niemieckiej 2 A nie zamierzało bronić Słupska i rozkazało, aby znajdujące się w rejonie miasta jednostki wycofały się za rzekę Łebę ${ }^{34}$.

${ }^{27}$ K. Rokossowski, Żołnierski..., s. 384-385.

${ }^{28}$ ЦАМО, f. 3401, о. 1, d. 38, Журнал боевых действий 3 гв. тк, b.m. 1 V 1945 r., k. 11.

${ }^{29}$ Sławno było prowizorycznie przygotowane do obrony. Od 28 II 1945 r. z inicjatywy władz miasta mieszkańcy wznosili barykady wzdłuż głównych ulic, ale budowa odbywała się bez nadzoru ze strony wojska, toteż powstałe konstrukcje posiadały nikłą wartość obronną. $\mathrm{Na}$ początku marca do miasta przybyły dwa bataliony 7 pgpanc. SS oraz członkowie Volkssturmu i Hitlerjugend. Dowódca obrony Sławna, kpt. Rosentreter (imienia nie ustalono), zamierzał utrzymać miasto do momentu zakończenia ewakuacji mieszkańców w kierunku Gdańska, Gdyni i Ustki. E. Murawski, Bój o Pomorze..., s. 211.

${ }^{30}$ Czasu środkowoeuropejskiego.

${ }^{31}$ Po opuszczeniu Sławna odcinek Ustka-Słupsk-Kobylnica zajął 7 pgpanc. SS, podczas gdy reszta dywizji wycofywała się z rejonu Miastka. Luka pomiędzy pułkiem a siłami głównymi dywizji wynosiła niemal $30 \mathrm{~km}$, dlatego pod komendę dowódcy 4 PDGPanc. SS. oddano 7 Dywizjon Rozpoznawczy z 7 DPanc. Dywizjon zajął pozycje od wsi Lubuń do Krępy Słupskiej, prowizorycznie zabezpieczając lewe skrzydło 7 pgpanc. SS od południa i odcięcia dróg odwrotu w kierunku Słupska.

${ }^{32}$ Dowództwo 27 DS zameldowało stratę jedynie 6 zabitych i 30 rannych. ЦАMO, f. 1024: 27 стрелковая дивизия (dalej: f. 1024), о. 1, d. 29, Боевое донесение штаба 27 сд, №145, Wieszyno 7 III 1945 r., k. 47.

${ }^{33}$ Po południu 6 III 1945 r. dowódca 3 KPanc. Gw. otrzymał rozkaz ze sztabu 19 A z zadaniem zdobycia Słupska do końca 8 III 1945 r. W przypadku napotkania zorganizowanego oporu korpus miał obejść miasto, pozostawiając jego zdobycie piechocie. ЦАMO, f. 46, o. 2394, d. 1409, Приказываю: 3 гв. тк с утра 7.3.45 перейти в наступление, b.m. 6 III 1945 r., k. 11; f. 1024, о. 1, d. 29, Боевое донесение штаба 27 сд, №145, Wieszyno 7 III 1945 r., k. 47.

${ }^{34}$ W Słupsku znajdował się sztab LV KA, grupa żołnierzy z 5 zapasowego dywizjonu kawalerii oraz oddział Volkssturmu. Komendantem garnizonu miasta był płk Diether von Kleist, 
3 KPanc. Gw. poruszał się w kierunku Słupska dwiema drogami. 3 i 18 BPanc. Gw., wsparte przez 1496 papanc., przegrupowały się marszrutą Warszkowo-Ścięgnica-Kończewo pod Kobylnicę, gdzie pod koniec dnia zajęły pozycje obronne ${ }^{35}$. 19 BPanc. Gw. z 1436 papanc. przemieszczała się po głównej drodze ze Sławna do Słupska. Utrudnienie stanowiły miny rozstawione na drodze, których wykryto 55 sztuk. Przed Noskowem Niemcy zorganizowali zasadzkę, ustawiając armaty ppanc. w lesie i wsi Wrześnica. Pułapka została w porę rozpoznana przez zwiadowców 19 BPanc. Gw. Podciągnięto baterię armat ZiS-3 ze składu brygady, która ostrzelała niemiecką pozycję, podczas gdy bataliony czołgów $\mathrm{z}$ dwiema bateriami dział pancernych SU-100 objechały ją od południa i zaatakowały nieprzyjaciela od tyłu ${ }^{36}$. Po zlikwidowaniu niemieckiej obrony brygada stosunkowo szybko znalazła się na przedmieściach Słupska, lecz gdy zwiadowcy donieśli o czołgach i działach przeciwpancernych na skraju miasta, zrezygnowano z ataku. Do wieczora czołgi 19 BPanc. Gw. zajęły wsie: Bolesławiec, Bierkowo, Włynkówko, blokując tym samym Słupsk od zachodu i północy. Za 19 BPanc. Gw. poruszała się 2 BZmot. Gw. Wymienione jednostki przegrupowały się do rejonu Kobylnicy, skąd wyjechały nad rzekę Słupię między Łosinem a Zajączkowem ${ }^{37}$.

Za jednostkami pancernymi przemieszczała się artyleria $3 \mathrm{KPanc}$. Gw. W godzinach popołudniowych 7 marca pierwsze jednostki artylerii dotarły do wsi Kończewo i Sierakowo Słupskie $(9,5 \mathrm{~km}$ na południowy zachód od Słupska). Zorganizowano tu stanowiska ogniowe. Do zachodu słońca we wspomnianych wsiach ześrodkowały się: 1072 Pułk Artylerii Lekkiej, 421 Pułk Artylerii Haubic, 324 Dywizjon Artylerii Rakietowej Gw., a także 375 Pułk Artylerii Pancernej Gw. i 266 Pułk Moździerzy. Po zmroku artyleria rozpoczęła ostrzał domniemanych pozycji nieprzyjaciela w południowej i zachodniej części Słupska, który trwał aż do godzin porannych następnego dnia ${ }^{38}$.

Wieczorem 7 marca Słupsk był blokowany z południa, zachodu i północy. Wciąż otwarta była droga na wschód. Pełne okrążenie miasta nie stanowiło

a następnie mjr Georg Jassa; ЦАMO, f. 46, o. 2394, d. 1186, Краткая сводка обобщенного боевого опыта войск 19 A, b.m. 14 IV 1945 r., k. 77; E. Murawski, Bój o Pomorze..., s. 211.

${ }^{35}$ ЦАМО, f. 3401, о. 1, d. 38, Журнал боевых действий 3 гв. тк, b.m. 1 V 1945 r., k. 12.

${ }^{36}$ ЦАМO, f. 46, о. 2404, d. 30, Отчет о боевых действиях 19 гв. тбр, b.m. 28 III 1945 r., k. 204.

${ }^{37}$ Pod Zajączkowem dowództwo 2 BZmot. Gw. wydzieliło oddział, który przeprawił się przez rzekę Słupię i przeszedł lasami pod wieś Płaszewko, gdzie przeprowadzono rozpoznanie i stworzono pozycję ogniową, z której planowano ostrzeliwać oddziały niemieckie kierujące się do Słupska z południa. ЦАМO, f. 3401, o. 1, d. 38, Журнал боевых действий 3 гв. тк, b.m. 1 V 1945 r., k. 12.

${ }^{38}$ ЦАМО, f. 46, о. 2404, d. 30, Доклад о боевой деятельности артиллерийских частей 3 гв. тк, b.m. 24 IV 1945 r., k. 98. 
priorytetu dla gen. Panfiłowa, gdyż liczył, że garnizon miasta wycofa się, unikając zniszczenia. Tak też się stało. Niemiecki odwrót z pozycji pod Słupskiem rozpoczął się przed godz. 24.007 marca, a zakończył o świcie. Dla sowieckiego generała była to sytuacja pożądana, gdyż w innym wypadku nie mógłby zdobyć miasta $\mathrm{w}$ tak krótkim czasie ${ }^{39}$.

Przed świtem 8 marca pod Słupsk podeszła 27 DS, co umożliwiło rozpoczęcie ataku. Piechota, wspierana przez 19 BPanc. Gw., natarła na zachodnie przedmieście miasta, podczas gdy czołgi T-34-85 3 BPanc. Gw. prowadziły ogień z miejsca w kierunku południowych zabudowań Słupska. W tym czasie 18 BPanc. Gw. sforsowała Słupię, przewożąc na pancerzach piechurów z 2 BZmot. Gw., po czym skierowała się na wschód, pozorując tym samym manewr okrążenia miasta. Do godz. 8.00 Słupsk został opanowany ${ }^{40}$.

Kolejnym celem sowieckiego natarcia był Lębork. 3 KPanc. Gw. rozpoczął marsz $\mathrm{w}$ kierunku tego miasta jeszcze w godzinach przedpołudniowych 8 marca. Podobnie jak poprzedniego dnia, korpus podzielił się na dwa zgrupowania. 18 i 3 BPanc. Gw. przemieszczały się główną drogą Słupsk-PoganiceLębork, zaś 19 BPanc. Gw. i 2 BZmot. Gw. szosą przez Głobino i Dobieszewo. W trakcie marszu oddział wydzielony 18 BPanc. Gw. wpadł w zasadzkę zorganizowaną w nocy przez żołnierzy z 7 pgpanc. SS z 6 armatami ppanc. ${ }^{41}$ Niemcy zniszczyli dwa czołgi i jedno działo pancerne. Opór nieprzyjaciela udało się złamać dopiero po podejściu sił głównych brygady. W wyniku godzinnego boju zameldowano rozbicie grupy żołnierzy nieprzyjaciela w sile kompanii. W tym samym czasie oddział wydzielony 19 BPanc. Gw. zniszczył trzy pojazdy nieprzyjaciela we wsi Malczkowo. Gdy jednostki 3 KPanc. Gw. zbliżyły się do rz. Łupawy, zwiadowcy z poszczególnych brygad przynieśli

\footnotetext{
${ }^{39}$ Jednostki 3 KPanc. Gw. stosunkowo szybko przegrupowały się przez Słupsk. W mieście zostali żołnierze 27 DS, a za nimi ściągały jednostki tyłowe i zabezpieczenia. Sowieccy żołnierze dopuścili się licznych morderstw i gwałtów na kobietach. W godzinach popołudniowych 9 III 1945 r. na rynek wjechała ciężarówka, z której ściągnięto skrzynie wypełnione uprzednio wykonanymi pochodniami - posłużyły one sowieckim żołnierzom do systematycznego podpalania miasta. Podobny los spotkał mieszkańców Sławna i Lęborka. Trudno wskazać przyczyny takiego postępowania. Sowieckie dokumenty dotyczące działań wojennych pod Słupskiem nie zawierają informacji na ten temat. Biorąc pod uwagę relacje z przebiegu wydarzeń z nocy 9 marca, można sądzić, że podpalenie Słupska miało wszelkie cechy planowego działania. Najpewniej był to sposób na zastraszenie ludności cywilnej tak, aby nie stawiała ona oporu w momencie gdy jednostki frontowe opuszczą miasto. Ponadto terror wymierzony w cywilów miał ułatwić późniejsze wysiedlenia ludności niemieckiej z ziem przyznanych Polsce $\mathrm{w}$ wyniku decyzji podjętych na konferencji jałtańskiej. Nie można wykluczyć, że miasto podpalono, aby stworzyć mit „ciężkich walk o Słupsk”, powielany później przez artykuły propagandowe w sowieckiej prasie. Sugeruje to fakt utrwalenia zniszczeń przez fotoreporterów; K.-H. Pagel, Der Landkreis..., s. 302.

${ }^{40}$ ЦАМО, f. 3401, о. 1, d. 38, Журнал боевых действий 3 гв. тк, b.m. 1 V 1945 r., k. 13.

${ }^{41}$ K.-H. Pagel, Der Landkreis..., s. 304.
} 
meldunki o obecności stanowisk artylerii ppanc. na jej prawym brzegu. $\mathrm{W}$ związku z powyższym gen. Panfiłow postanowił przełożyć forsowanie rzeki na dzień następny. W efekcie do końca dnia $3 \mathrm{KPanc}$. Gw. pokonał zaledwie $22-33 \mathrm{~km}^{42}$.

Dowództwo niemieckiej 2 A traktowało odcinek rzeki Łupawy jako pozycję opóźniającą. Zatrzymanie wojsk sowieckich na lewym brzegu rzeki dało czas na zorganizowanie kolejnej linii oporu. Biorąc pod uwagę warunki terenowe, zadecydowano, że najlepszym ośrodkiem oporu będzie wieś Pogorzelice, usytuowana na zboczu moreny dennej. Od południa dostępu do wsi broniły liczne zalesione pagórki oraz wzniesienia nr 110,4 i 70,3. Natomiast z kierunku północno-zachodniego ruch utrudniała kotlina rz. Pogorzelicy, która na odcinku $3 \mathrm{~km}$ biegnie równolegle do szosy ze Słupska do Lęborka. Szosa, wzdłuż której poruszała się kolumna sowieckich czołgów, od północy była ograniczona nasypem kolejowym, biegnącym równolegle do drogi, zaś od południa korytem rz. Pogorzelicy. Owe warunki spowodowały, że było to miejsce wyjątkowo dogodne do zorganizowania zasadzki ${ }^{43}$.

Przed świtem 9 marca do Pogorzelic przybył 4 Dywizjon Przeciwlotniczy SS (dplot) ${ }^{44}$. Bronili się tu również żołnierze jednego z pododdziałów 7 pgpanc. $\mathrm{SS}^{45}$. Armaty przeciwlotnicze kal. $88 \mathrm{~mm}$ rozstawiono pomiędzy zabudowaniami wsi, wzdłuż północnego stoku moreny, między folwarkiem Stare Ositno a młynem w Pogorzelicach oraz w rejonie stacji kolejowej i fabryki szkła w Leśnicach.

Nocą z 8 na 9 marca w rejon Poganic podeszli saperzy 3 KPanc. Gw. i przystąpili do konstruowania przepraw przez rzekę. O świcie 9 marca $3 \mathrm{KPanc}$. Gw. przeprawił się przez Łupawę, rozpoczynając ruch w kierunku Lęborka. $\mathrm{W}$ awangardzie korpusu poruszała się 18 BPanc. Gw., a za nią 3 BPanc. Gw.

Rankiem 18 BPanc. Gw. pokonała Łupawę i ostrzelała grupę niemieckich zwiadowców na prawym brzegu rzeki. Do godz. 14.00 czołgi podjechały pod wieś Pogorzelice. W momencie gdy czołgi znalazły się kilkaset metrów przed pierwszymi zabudowaniami wsi, jadący na przedzie kolumny T-34-85 został trafiony pociskiem w lewą burtę wieży. Ogień otwarto od strony nasypu kolejowego. Według relacji mieszkańców wsi strzelał pociąg pancerny

${ }^{42}$ ЦАМО, f. 3401, о. 1, d. 38, Журнал боевых действий 3 гв. тк, b.m. 1 V 1945 r., k. 13-14.

${ }^{43}$ A. Barański, Pogorzelice, 09-10 marca 1945 r. Studium - bitwa czy potyczka?, „Biuletyn Historyczny Lęborskiego Bractwa Historycznego i Muzeum w Lęborku” 2006, nr 29, s. 19.

${ }^{44}$ Ibidem, s. 18.

${ }^{45} \mathrm{Na}$ podstawie nieśmiertelników odnalezionych w Pogorzelicach Andrzej Barański podaje, że we wsi bronił się 7 Batalion Szkolny SS ze Starego Bornego. Wydaje się to wątpliwe, ponieważ wspomniany batalion przynależał do 7 Dywizji Górskiej SS „Prinz Eugen”, która walczyła na Bałkanach. Najprawdopodobniej wspomniane nieśmiertelniki należały do żołnierzy 7 pgpanc. SS, którzy toczyli walki odwrotowe wzdłuż szosy Słupsk-Lębork; ibidem, s. 19. 
lub czołg przewożony na platformie kolejowej ${ }^{46}$. Po chwili sowiecki czołg zaczął płonąć, a kolumna znalazła się pod ogniem karabinów maszynowych $\mathrm{z}$ budynku kolejowego. Przewożeni na pancerzach fizylierzy ${ }^{47}$ schronili się za kadłubami czołgów lub rozbiegli się na pola. Według jednej z relacji na wieży nieistniejącego już dziś kościoła siedział snajper i strzelał do sowieckich oficerów. Kolumna, osłaniając się ogniem armat i karabinów maszynowych, wycofała się poza zasięg niemieckich dział ppanc. Godzinę później w rejon potyczki przybyła także 3 BPanc. Gw., jednak nie podjęto już dalszej walki.

Na rozkaz dowódcy artylerii korpusu, płk. Michaiła Bieljakowa, pod Pogorzelice podciągnięto 1072 Pułk Artylerii Lekkiej i jeden z pułków 166 Brygady Artylerii Lekkiej ${ }^{48}$. Lekkie haubice rozstawiono niecałe $0,5 \mathrm{~km}$ od wsi i rozpoczęto prowadzenie ognia na wprost do jej zabudowań ${ }^{49}$. Następnie w rejon Pogorzelic przybył 324 Dywizjon Artylerii Rakietowej Gw., uzbrojony w wyrzutnie rakiet M-13. Dwie baterie tego dywizjonu wystrzeliły salwę rakiet w kierunku zabudowań wsi, po czym cała jednostka ostrzelała stację kolejową ${ }^{50}$.

W związku z podejściem do rz. Łupawy piechurów 19 A, 19 BPanc. Gw. i 2 BZmot. Gw. otrzymały drogą radiową rozkaz gen. Panfiłowa o zmianie osi natarcia, celem obejścia pozycji w Pogorzelicach i kontynuowania uderzenia na Lębork. Wykonując rozkaz, brygady zmieniły kierunek działań ze wschodniego na północny wzdłuż drogi: Skórowo-Rzechcino-Stowięcino-Gorzyno-Przybrodzie. W Stowięcinie ostrzelano czołg prowadzący z Panzerfausta. Po krótkiej strzelaninie odrzucono nieprzyjaciela, który okazał się strażą tylną 5 Zapasowego Dywizjonu Kawalerii. Po minięciu Przybrodzia napotkano dwa nienaruszone mosty: jeden przez Łebę, drugi przez Kanał Łebski. Następnie kolumna sowieckich czołgów skierowała się w stronę Nowej Wsi Lęborskiej. Wjeżdżająca do wsi Żelazkowo 19 BPanc. Gw. dostała się pod ogień moździerzy prowadzony od strony Redkowic, gdzie broniła się reszta 5 Zapasowego Dywizjonu Kawalerii ${ }^{51}$. Zwiadowcy zameldowali o obecności dział pancernych w sąsiedniej wsi, toteż czołgiści zamaskowali swoje maszyny

\footnotetext{
${ }^{46}$ Ibidem, s. 20.

${ }^{47}$ Mowa o żołnierzach lekkiej piechoty z batalionu fizylierów zmotoryzowanych 18 BPanc. Gw., uzbrojonych w pistolety maszynowe i szkolonych do walki w roli desantu na pancerzach czołgów T-34.

${ }^{48}$ Ze składu 1 Dywizji Artylerii Przełamania 19 A.

${ }^{49}$ A. Barański, Pogorzelice..., s. 23.

${ }^{50}$ ЦАМО, f. 46, о. 2404, d. 30, Доклад о боевой деятельности артиллерийских частей 3 гв. тк, b.m. 28 III 1945 r., k. 99.
}

${ }^{51}$ ЦАМО, f. 3401, о. 1, d. 38, Журнал боевых действий 3 гв. тк, b.m. 1 V 1945 r., k. 14. 
w Żelazkowie w oczekiwaniu na piechotę 2 BZmot. Gw. Po przybyciu piechurów zaatakowano Redkowice, opanowując wieś bez strat ${ }^{52}$.

Gdy w godzinach popołudniowych dotarła wiadomość, że Pogorzelice można wyminąć od północy, w ślad za 19 BPanc. Gw. ruszyła 3 BPanc. Gw. z 1436 papanc. W tym czasie 18 BPanc. Gw. pozostawała pod Pogorzelicami. Przed południem w rejon walk podeszła 101 DSGw., która nacierała w pierwszym rzucie $40 \mathrm{KSG}$. Żołnierze dywizji przekroczyli Łupawę pod Poganicami i rozpoczęli natarcie na Pogorzelice siłami 321 i 329 Pułków Strzeleckich Gw. (p. strz. Gw.). Do godz. 16.00 wieś została opanowana ${ }^{53}$, a żołnierze 101 DSGw. ruszyli w pościg za nieprzyjacielem w kierunku Lęborka ${ }^{54}$. Wraz z piechotą jechały czołgi 18 BPanc. Gw. Piechurzy zostali posadzeni na pancerze czołgów $\mathrm{w}$ roli desantu. Tak sformowana kolumna wjechała do Lęborka od zachodu, podczas gdy w mieście przebywały jeszcze niemieckie straże tylne. Doszło do wymiany ognia, lecz Niemcy nie zamierzali bronić Lęborka i szybko odstąpili ${ }^{55}$.

W czasie gdy czołgi 18 BPanc. Gw. poruszały się wspierając piechotę, powoli i systematycznie oczyszczającą zabudowania Lęborka, reszta 3 KPanc. Gw. kontynuowała działania zaczepne w kierunku wschodnim.

Do świtu 10 marca 19 BPanc. Gw. wraz z 1496 papanc. uporała się z siłami nieprzyjaciela pod Redkowicami, a następnie ruszyła drogą przez Nową Wieś Lęborską-Kębłowo-Nowowiejskie-Kisewo. W trakcie marszu napotkano liczne zawały leśne, miny oraz improwizowane ładunki wybuchowe

${ }^{52}$ ЦАМО, f. 46, о. 2404, d. 30, Отчет о боевых действиях 19 гв. тбр, b.m. 28 III 1945 r., k. 208.

${ }^{53}$ W czasie walk 9 III 1945 r. 101 DSGw. straciła 12 zabitych i 32 rannych. Większą część tych strat poniesiono w wyniku boju o Pogorzelice. Dowództwo dywizji zameldowało, że wzięto do niewoli 40 żołnierzy niemieckich, zdobyto 8 karabinów maszynowych, 22 karabiny i 4 samochody. Straty nieprzyjaciela oceniono na 50 zabitych i 60 rannych; ЦАМО, f. 917: 101 гвардейская стрелковая дивизия (dalej: f. 917), o. 1, d. 160, Журнал боевых действий 101 гв. сд, b.m. 9 V 1945 r., k. 57.

${ }^{54}$ Ewakuacja Lęborka rozpoczęła się w momencie, gdy od strony Słupska zaczął dobiegać huk wystrzałów artylerii sowieckiej. Ludność cywilna opuszczała miasto, kierując się w stronę Wejherowa i Pucka. W Lęborku znajdowały się jeszcze pozostałości niemieckich oddziałów, szpital marynarki wojennej, szpital dywizyjny oraz szpital dla rosyjskich żołnierzy z oddziałów gen. Andrieja Własowa. Wycofanie tych placówek nastąpiło 9 III 1945 r. Również sformowany w mieście oddział Volkssturmu wymaszerował na wschód; E. Murawski, Bój o Pomorze..., s. 213.

${ }^{55}$ Pomimo że Lębork nie był broniony, a strzelanina w zachodniej dzielnicy miasta trwała krótko, nie obyło się bez ofiar. 101 DSGw. straciła 18 zabitych i 87 rannych. Są to stosunkowo wysokie straty, biorąc pod uwagę przebieg walk, co może świadczyć o tym, że część Rosjan padła ofiarą min pułapek lub innych wypadków; ЦАMO, f. 917, o. 1, d. 160, Журнал боевых действий 101 гв. сд, b.m. 9 V 1945 r., k. 57. 
wykonane $\mathrm{z}$ amunicji artyleryjskiej. Rozbito kilka doraźnie zorganizowanych punktów oporu i nawiązano kontakt bojowy z ariergardą nieprzyjaciela. W godzinach popołudniowych brygada dotarła do wsi Łeba, w której znajdował się most przez rzekę o tej samej nazwie. Pomiędzy domami stały wraki trzech czołgów i czterech dział pancernych, samozniszczonych w pośpiechu przez nieprzyjaciela. Co zaskakujące, most na rzece Łebie był nienaruszony. Brygada kontynuowała szybki marsz na wschód, dochodząc do przystanku kolejowego Bożepole Małe, gdzie napotkano dwa przewożące czołgi składy kolejowe oczekujące na podstawienie lokomotyw. Najpewniej czołgi nie były zatankowane, ponieważ ich załogi nie podjęły próby zjechania $\mathrm{z}$ lor $\mathrm{w}$ teren, a jedynie odpowiadały ogniem $\mathrm{z}$ platform ${ }^{56}$. W wyniku godzinnej walki zniszczono unieruchomione czołgi nieprzyjaciela i opanowano stację wraz z całą wsią Bożepole Małe. Przy okazji zdobyto wiele sprawnych pojazdów i skład mienia wojskowego. Nie był to koniec działań 19 BPanc. Gw. Tuż po zmroku czołgi dojechały do dużej wsi Luzino, gdzie przekroczyły małą rzeczkę Bolszewka, podjeżdżając do wsi Małe Gowino - 3,5 km na południe od Wejherowa. Podążająca za czołgami 2 BZmot. Gw. dotarła do wsi Gościcino i Małe Gowino ${ }^{57}$.

Początkowo 3 BPanc. Gw. z 1436 papanc. poruszała się o krok za 19 BPanc. Gw. Drogi obu jednostek rozdzieliły się w Łęczycach. 3 Brygada zamiast na południe, skierowała się na północny wschód do wsi Chynowie. Ruch pododdziałów był hamowany przez uchodźców, którzy tarasowali wąską szosę. Po minięciu Chynowia czołgi dojechały do Strzebielina, wsi położonej przy trasie z Lęborka do Wejherowa. Na drodze stłoczone były liczne niemieckie ciężarówki, ciągniki holujące artylerię, transportery opancerzone i liczne wozy konne. Były to przemieszane jednostki VII KPanc., które w pośpiechu wycofywały się w kierunku Wejherowa. Czołgi T-34-85 i działa pancerne SU-100 natychmiast rozpoczęły ostrzał pojazdów nieprzyjaciela. W niemieckiej kolumnie zapanowała panika. Żołnierze, uciekając w pola, w popłochu porzucali pojazdy i broń. Brygada, chcąc maksymalnie wykorzystać efekt zaskoczenia, ruszyła szosą w stronę Wejherowa. Czołgi prowadziły ciągły ogień z broni maszynowej i gąsienicami miażdżyły stłoczone pojazdy. Niemiecka kolumna miała długość $3 \mathrm{~km}$ - aż do Charwatynia. Liczne pojazdy niemieckie stały po obu stronach drogi i na poboczach zgrupowane w 5-6 rzędów ${ }^{58}$. W korku utknął m.in. 4 dplot. SS, wycofujący się spod Lęborka.

\footnotetext{
${ }^{56}$ Prawdopodobne, że był to transport 50 czołgów przeznaczonych jako uzupełnienie dla 7 DPanc., o którym wspominał gen. Karl Mauss, dowódca dywizji. Zob. P. Buttar, Pole walki Prusy: szturm na niemiecki front wschodni 1944-1945, Poznań 2011, s. 483-484.

${ }^{57}$ ЦАМО, f. 3401, о. 1, d. 38, Журнал боевых действий 3 гв. тк, b.m. 1 V 1945 r., k. 15.

${ }^{58}$ ЦАМО, f. 46, о. 2404, d. 30, Доклад о боевых действий 3 гв. тбр, b.m. 3 IV 1945 r., k. 170.
} 
W ogniu sowieckich wozów dywizjon stracił wszystkie armaty i środki transportu, a ocaleli żołnierze zostali zmuszeni do walki jako zwykła piechota ${ }^{59}$.

Z wyliczeń dowódcy 3 BPanc. Gw. wynika, że zniszczonych zostało: 2,3 tys. samochodów i wozów konnych, 80 dział dużego kalibru, 20 transporterów opancerzonych, 35 sześciolufowych wyrzutni rakiet Nebelwerfer, 13 dział samobieżnych i 40 karabinów maszynowych. Zabitych lub rannych miało zostać ok. 1 tys. oficerów i żołnierzy nieprzyjaciela, a ok. 2 tys. rozbiegło się w panice po lasach. Według szefa sztabu 3 BPanc. Gw., ppłk. Mendla Kogana, żołnierze brygady jeszcze nigdy nie widzieli takiego pogromu wojsk nieprzyjaciela w jednym starciu. Nawet jeżeli założyć, że podane liczby są zawyżone, to nie ulega wątpliwości, że 3 BPanc. Gw. zadała nieprzyjacielowi znaczące straty ${ }^{60}$.

Po rozbiciu nieprzyjacielskiej kolumny 3 BPanc. Gw. skierowała się na Nowe Kębłowo i dalej w kierunku Wejherowa. Jeszcze przed zmrokiem oddział wydzielony brygady wjechał do Bolszewa. Czołgi, poruszając się szosą z Charwatynia do Wejherowa, na wysokości Bolszewa wpadły pod ogień armat przeciwlotniczych kal. $88 \mathrm{~mm}$, prowadzących ostrzał z zamaskowanych pozycji na przedpolu Wejherowa. Chwilę później niemiecka artyleria z rejonu na północ i południe od Wejherowa ostrzelała Bolszewo. Ogniem haubicznym nakryta została kolumna samochodów 3 BPanc. Gw. wjeżdżająca do wsi ${ }^{61}$. W wyniku paniki, jaka zapanowała, brygada wycofała się z Bolszewa, ponosząc następujące straty: 13 zabitych, 47 rannych, 7 zniszczonych T-34-85 i 5 kolejnych uszkodzonych, 1 zniszczone działo pancerne SU-100 ${ }^{62}$. Do zmroku brygada ześrodkowała się w Gościcinie - $5 \mathrm{~km}$ na zachód od Wejherowa, gdzie zamaskowano czołgi i zorganizowano obronę okrężną ${ }^{63}$.

Pomimo poniesionych strat dowódca 3 BPanc. Gw. nie zrezygnował z zamiaru kontynuowania walki i postanowił odbić Bolszewo, zajęte ponownie przez żołnierzy niemieckich uzbrojonych w Panzerfausty. Około godz. 22.00, pod osłoną ciemności, wieś zaatakował batalion fizylierów zmotoryzowanych

${ }^{59}$ F. Husemann, Die guten Glaubens waren: Geschichte der SS-Polizei-Division (4.SS-Polizei-Panzer-Grenadier-Division), t. 2: 1943-1945, Osnabrück 1971, s. 511.

${ }^{60}$ ЦАМО, f. 46, о. 2404, d. 30, Доклад о боевых действий 3 гв. тбр, b.m. 3 IV 1945 r., k. 170 .

${ }^{61}$ Szosa główna z Lęborka do Wejherowa była zatarasowana wrakami pojazdów i trupami końskimi, przez co była nieprzejezdna dla pojazdów kołowych. Kolumny samochodów próbowały ominąć zatory, poruszając się bocznymi drogami, dlatego koncentracja rzutu kołowego brygady w rejonie walk trwała do godzin porannych 11 III 1945 r.; ibidem.

${ }^{62} \mathrm{~W}$ rejonie Bolszewa działała grupa niemieckich piechurów uzbrojonych w granatniki typu Panzerfaust, zatem niewykluczone, że co najmniej kilka czołgów padło ich ofiarą. Sugeruje to liczba zniszczonych czołgów.

${ }^{63}$ ЦАМО, f. 46, о. 2404, d. 30, Доклад о боевых действий 3 гв. тбр, b.m. 3 IV 1945 r., k. 170 . 
3 BPanc. Gw. Fizylierzy, jadąc na rozpędzonych ciężarówkach, prowadzili ciągły ogień z pistoletów maszynowych, a gdy znaleźli się w centrum wsi, rzucili się do walki wręcz. Ryzykowna taktyka przyniosła pożądany rezultat. Nagłe pojawienie się Sowietów uniemożliwiło Niemcom wykorzystanie przewagi w artylerii. Po trzygodzinnej walce Bolszewo zostało opanowane. W gwałtownej walce batalion fizylierów zmotoryzowanych stracił 3 zabitych, 28 rannych i 2 zaginionych ${ }^{64}$. Po zdobyciu Bolszewa kolejnym celem brygady było oddalone o $4 \mathrm{~km}$ Wejherowo.

Wejherowa bronili 16- i 17-letni członkowie Służby Pracy Rzeszy (Reichsarbeitsdienst), którzy zostali doraźnie przeszkoleni w obsłudze armat przeciwlotniczych Flak 18 kal. 88 mm, używanych do zwalczania broni pancernej. Oprócz tego w mieście znajdowali się członkowie Volkssturmu oraz żołnierze oddziałów tyłowych ${ }^{65}$.

Dla oddziałów niemieckiej 2 A Wejherowo stanowiło istotny punkt oporu, ponieważ leżało na trasie Słupsk-Lębork-Reda-Gdynia w najwęższym miejscu Pradoliny Redy-Łeby. Przemieszczały się tędy liczne pododdziały 4 PDGPanc. SS, 7 DPanc. i 226 BDzSzt. Utrata miasta była jednoznaczna $\mathrm{z}$ otwarciem sowieckim wojskom drogi w kierunku Redy i dalej na Gdynię i Puck. Doceniając położenie Wejherowa, dowódca 4 PDGPanc. SS, SS-Standartenführer ${ }^{66}$ Walter Harzer, postanowił skierować do obrony miasta 4 Batalion Zapasowy SS ${ }^{67}$.

O świcie 11 marca, w rejon rozlokowania 3 BPanc. Gw. podjechały ciężkie działa pancerne ISU-122 z 375 papanc. Gw., które miały wesprzeć czołgistów w boju o Wejherowo. Po pewnym czasie nadleciały samoloty szturmowe Ił-2, które ostrzalały z broni pokładowej i rakiet miasto. O 13.30 rozpoczął się szturm Wejherowa. Batalion fizylierów zmotoryzowanych 3 BPanc. Gw. zaatakował przystanek kolejowy i cementownię na północno-zachodnim skraju miasta. Czołgi posuwały się za piechotą przez podmokłą łąkę w kierunku zachodnich zabudowań. Gdy pierwszy T-34-85 wyjechał na wysokość cementowni, kolumna dostała się pod ogień artylerii. Uznano, że cementownia stanowi punkt obserwacyjny dla niemieckiej artylerii, toteż do ataku na obiekt ruszyli fizylierzy brygady, a za nimi cztery czołgi, które manewrem od północy próbowały objechać budynki. Niemcy przewidzieli ten ruch i ukryli w lesie za cementownią armatę ppanc. ${ }^{68}$ Ogień z zamaskowanego

${ }^{64}$ ЦАМО, f. 3067: 3 гвардейская танковая бригада (dalej: f. 3067), o. 1, d. 25, Журнал боевых действий мотострелкового батальона автоматчиков 3 гв. тбр, b.m. 3 XII 1946 r., k. 161.

${ }^{65}$ F. Husemann, Die guten Glaubens..., s. 502.

${ }^{66}$ Stopień odpowiadający stopniowi pułkownika (Oberst) w Wehrmachcie.

${ }^{67}$ F. Husemann, Die guten Glaubens..., s. 502.

${ }^{68} \mathrm{~W}$ lesie, na prawo od drogi prowadzącej w kierunku Wielkiej Piaśnicy. 
działa zniszczył dwa T-34-85, a kolejne dwa ciężko uszkodził. Pozostałe czołgi T-34-85 wycofały się do Bolszewa, atak przerwano ${ }^{69}$. Na polu walki poległo dwóch fizylierów, a 6 zostało rannych ${ }^{70}$.

W zaistniałej sytuacji 19 BPanc. Gw. podjęła próbę okrążenia Wejherowa od południa. Ale gdy czołgi zagłębiły się w las, wykorzystując przy tym wąskie dukty w pofałdowanym terenie, stwierdzono, że manewr jest zbyt ryzykowny bez wsparcia dużych sił piechoty i odstąpiono od tego pomysłu. Działania na tym odcinku kontynuował 1 batalion z 2 Brygady Motocyklowej Gw. Sowieccy motocykliści, poruszając się z Gościcina, minęli Pętkowice i ruszyli w kierunku południowo-zachodnich zabudowań Wejherowa. Około godz. 14.00, 1,5 km na północny zachód od Pętkowic, batalion został ostrzelany z moździerzy i karabinów maszynowych. Po krótkiej wymianie ognia motocykliści wycofali się do Gościcina, gdzie znajdowała się reszta brygady. $\mathrm{W}$ walce życie straciło 5 żołnierzy, a 11 zostało rannych ${ }^{71}$.

Po tych niepowodzeniach gen. Panfiłow postanowił wstrzymać się z kolejnym natarciem aż do nadejścia dywizji $19 \mathrm{~A}^{72}$. O godz. 19.45 do sztabu 3 KPanc. Gw. wpłynął szyfrogram nr 5819/m. z dowództwa 2 F. Biał., w którym marsz. Rokossowski przekazał informację, że skierował pod Wejherowo 8 Korpus Zmechanizowany Gwardii (KZmech. Gw.) z 1 APanc. Gw. i rozkazał gen. Panfiłowowi rozpocząć przegrupowanie na południe, w kierunku wsi Szemud, skąd jego korpus miał uderzyć na zachód i wyjść nad brzeg Morza Bałtyckiego pod Kolibkami ${ }^{73}$. Manewr ten miał na celu odcięcie gdyńskiego zgrupowania wojsk niemieckich od Sopotu i Gdańska. Od tego momentu $3 \mathrm{KPanc}$. Gw. został podporządkowany dowództwu $70 \mathrm{~A}^{74}$.

Warunki do wprowadzenia 1 APanc. Gw. do bitwy zaistniały po zdobyciu Słupska. Początkowo marsz. Rokossowski planował wykorzystać armię do rozbicia niemieckiej obrony wzdłuż Łupawy. Szerokość koryta tej rzeki dochodziła niekiedy nawet do $20 \mathrm{~m}$, a wiosenny przybór wód czynił z niej niebezpieczną przeszkodę na drodze sowieckich wojsk. Dowódca 2 F. Biał. obawiał się, że Niemcy wykorzystają sprzyjające warunki hydrograficzne

${ }^{69}$ ЦАМО, f. 3067, о. 1, d. 23, Журнал боевых действий 1 тб 3 гв. тбр, b.m. 20 IX 1945 r., k. 69.

${ }^{70}$ Ibidem, d. 25, Журнал боевых действий мотострелкового батальона автоматчиков 3 гв. тбр, b.m. 3 XII 1946 r., k. 161.

${ }^{71}$ Były to jedyne straty brygady poniesione w okresie 7-11 III 1945 r., zob. ЦАМO, f. 3363: 2 гвардейская мотострелковая бригада, о. 1, d. 16, Журнал боевых действий 2 гв. мсбр, b.m. 3 V 1945 r., k. 20.

72 ЦАМО, f. 46, о. 2404, d. 30, Отчет о боевых действиях 19 гв. тбр, b.m. 28 III 1945 r., k. 208.

${ }^{73}$ Osiedle na południe od Gdyni.

${ }^{74}$ ЦАМО, f. 3401, о. 1, d. 38, Журнал боевых действий 3 гв. тк, b.m. 1 V 1945 r., k. 16. 
do organizacji trwałej obrony wzdłuż rzeki, której przełamanie kosztowałoby dużo czasu i istnień ludzkich. Jednak po zajęciu Słupska i Lęborka okazało się, że opór Niemców jest dużo słabszy, niż początkowo podejrzewano. Dowództwo 2 F. Biał. uświadomiło sobie, że nieprzyjaciel wycofuje się, aby zorganizować defensywę opartą o wzgórza wokół Gdyni i Gdańska. Nowym zadaniem 1 APanc. Gw. miało być niedopuszczenie do takiego rozwoju wypadków. Jeszcze 8 marca marsz. Rokossowski wystosował do dowództwa armii szyfrogram nr 5556, w którym wydał rozkaz zdobycia siłami 1 APanc. Gw. Gdyni i Pucka do końca dn. 12 marca $^{75}$.

Trzon 1 APanc. Gw. stanowiły dwa korpusy: 11 KPanc. Gw. i 8 KZmech. Gw. Ponadto w skład armii wchodziły: 64 BPanc Gw., 19 Brygada Artylerii Pancernej, 197 Brygada Artylerii Lekkiej, 17 Brygada Saperów, 11 Pułk Czołgów Ciężkich Gw. i szereg innych, mniejszych jednostek zabezpieczania i wsparcia. Dnia 10 marca armia dysponowała 302 czołgami i 153 działami pancernymi ${ }^{76}$. W myśl rozkazów gen. Katukowa zadanie zdobycia Pucka otrzymało dowództwo $11 \mathrm{KPanc}$. Gw., zaś $8 \mathrm{KZmech}$. Gw. miał wykonać uderzenie wzdłuż Pradoliny Redy-Łeby, celem którego była Gdynia. Oba korpusy stanowiły pierwszy rzut armii, natomiast armijne jednostki wsparcia znajdowały się w drugim rzucie. Ugrupowanie armii sugeruje, iż gen. Katukow spodziewał się, że korpusy zrealizują postawione im zadania bez większych problemów.

8 KZmech. Gw. był dowodzony przez gen. mjr. Iwana Driemowa. W skład korpusu wchodziły ${ }^{77}$ : dowództwo i sztab; 19, 20 i 21 Brygady Zmechanizowane Gw. (BZmech. Gw.), 1 BPanc. Gw., 155 Batalion Łączności Gw., 133 Batalion Saperów Gw., 561 Polowa Baza Remontu Czołgów, 562 Polowa Baza Remontu Samochodów, 138 Piekarnia Polowa, 1775 Kasa Banku Polowego, 2310 Poczta Polowa. Ponadto dowództwu 8 KZmech. Gw. podporządkowano szereg jednostek wsparcia: 353 i 400 papanc. Gw., 265 Pułk Moździerzy, 358 Pułk Artylerii Przeciwlotniczej Gw., 8 bmot. Gw., 405 Dywizjon Rakietowy Gw.

12 marca 1945 r. 8 KZmech. Gw. liczył 13 tys. ludzi, a wraz z oddziałami przydzielonymi dysponował liczbą: 88 czołgów T-34-85, 28 dział pancernych (16 SU-76M, 9 SU-85 i 3 SU-57), 49 armat, 105 moździerzy, 6 wyrzutni rakiet oraz 28 armat plot. i karabinami maszynowymi. Warto zaznaczyć, że korpus był znacząco słabszy od luzowanego pod Wejherowem 3 KPanc. Gw. Po uwzględnieniu jednostek pancernych 19 A stosunek sił pomiędzy sowieckimi a niemieckimi jednostki pancernymi zmienił się z 3:1 na 2,4:1.

${ }^{75}$ ЦАМО, f. 299, о. 3070, d. 759, Доклад о боевых действиях 1 гв. ТА, b.m. 23 V 1945 r., s. 28.

${ }^{76}$ Ibidem, s. 26.

${ }^{77}$ http://tankfront.ru/ussr/mk/gvmk08.html (dostęp 18 X 2018 r.). 
Nieoczekiwanie, 8 marca 1945 r., armia pancerna gen. Katukowa otrzymała „Wzmocnienie” w postaci 1 BPanc. im. Bohaterów Westerplatte ${ }^{78}$, należącej do „ludowego" Wojska Polskiego ${ }^{79}$. Etat jednostki opiewał na 1446 ludzi i 65 czołgów T-34-85. Jednak na skutek walk prowadzonych od połowy stycznia do 7 marca jednostka dysponowała jedynie 9 z 65 czołgów przewidzianych etatem, zaś do rejonu koncentracji $8 \mathrm{KZmech}$. Gw. dotarły tylko trzy ${ }^{80}$.

9 marca $8 \mathrm{KZmech}$. Gw. skoncentrował się w odległości $22 \mathrm{~km}$ na zachód od Słupska. Zgodnie z rozkazami gen. Katukowa korpus miał zrealizować następujące zadanie: „8 Gw. K[orpus] Z[mechanizowany] z 1 P[olską] B[rygadą] P[ancerną] i pułkiem plot. od rana 10.3.1945 roku z rubieży Łupawa, Rzechcino wykona uderzenie w kierunku Wejherowa na kierunku: Pogorzelice, Niebędzino i zniszczy przeciwdziałającego nieprzyjaciela do końca dnia 10.3.1945 roku[,] głównymi siłami korpusu wyjdzie w rejon: Luzino, Góra, Chynowie, Strzebielino. Przednimi oddziałami zdobyć węzeł dróg w Wejherowie. Następnie, kontynuować szybkie natarcie 11.3.1945 r. głównymi siłami korpusu wyjść nad brzeg Zatoki Gdańskiej, na rubieży Gdynia, Żelistrzewo"s1.

Wykonując postawione zadanie, do południa 11 marca pododdziały $8 \mathrm{KZmech}$. Gw. przegrupowały się w rejon Bolszewa ${ }^{82}$-Charwatynia-Nowego Kłębowa-Orlego-Zelewa, gdzie zastały 3 KPanc. Gw., toczący walkę

${ }^{78} \mathrm{Z}$ uwagi na fakt, że w opisywanej bitwie walczyła także 1 Brygada Pancerna Gw., autor zdecydował się pozostawić tytuł patronów polskiej brygady dla odróżnienia jej w tekście od sowieckiej jednostki. Na temat 1 BPanc. im. Bohaterów Westerplatte zob. K. Anduła, 1. Warszawska Brygada Pancerna im. Bohaterów Westerplatte na froncie (1943-1945), Warszawa 2015, passim.

${ }^{79}$ Zarówno 1 BPanc. im. Bohaterów Westerplatte, jak i 1 APanc. Gw. zostały wymienione w dyrektywie Stawki nr 11035 z 5 III 1945 r., w której określono zadanie 2 F. Biał. Dyrektywa była sygnowana podpisem Józefa Stalina oraz gen. armii Aleksieja Antonowa; zob. № 311: Директива Ставки ВГК № 11035 командующему войсками 2-го белорусского фронта на развитие операции в восточной Пруссии [w:] Русский архив, s. 206.

${ }^{80}$ ЦАМО, f. 299, о. 3070, d. 827, Журнал боевых действий 1 гв. ТА, b.m. 9 V 1945 r., k. 115.

${ }^{81}$ Podano polskie nazwy geograficzne w miejsce niemieckich, którymi posługiwał się autor dokumentu; ibidem, k. 116.

${ }^{82}$ W rejonie lasów i linii kolejowej na północ od Bolszewa czołgiści 1 BPanc. Gw. odnaleźli duże składowisko porzuconego mienia wojskowego, artylerii i pojazdów. Odkryto tu także prowizoryczny obóz, w którym przetrzymywano więźniów różnych narodowości $\mathrm{z}$ ewakuowanego Konzentrationslager "Stutthof”. W dokumentach jednostki podano, że oswobodzono 45 tys. ludzi, lecz liczba ta jest wielokrotnie przesadzona, gdyż faktycznie w rejonie tym przebywało kilkuset więźniów i uciekinierów; ЦАМО, f. 3440: 1 гвардейская танковая бригада (dalej: f. 3440), o. 1, d. 113, Выписка из журнала боевых действий 1 гв. тбр, b.m. 26 III 1945 r., k. 140; J. Grabowska-Chałka, Stutthof. Informator historyczny, Gdańsk-Sztutowo 2014, s. 111. 
o Wejherowo. Genenerał Driemow postanowił wesprzeć gen. Panfiłowa w próbie zdobycia miasta, kierując do walki 1 BPanc. Gw. ${ }^{83}$ Wykonując rozkaz dowódcy korpusu, czołgi 1 BPanc. Gw. uderzyły wzdłuż szosy z Lęborka. Błotnista łąka na lewo od drogi nie pozwoliła batalionom czołgów na rozwinięcie szyku, toteż poruszały się one w kolumnie, stanowiąc tym samym łatwy cel dla niemieckiej broni przeciwpancernej. Ogień armat plot. kal. $88 \mathrm{~mm}$ zniszczył 6 czołgów i 3 działa pancerne. Wobec silnej obrony przeciwpancernej i zapadających ciemności atak na Wejherowo odłożono na następny dzień ${ }^{84}$.

W trakcie boju o Wejherowo trwało odtwarzanie potencjału bojowego 1 BPanc. im. Bohaterów Westerplatte. Jeszcze 8 marca 1945 r. brygada otrzymała, jako uzupełnienie, 60 żołnierzy z 2 Warszawskiej DP im. Henryka Dąbrowskiego. 11 marca w szeregi jednostki przybyło 15 czołgów T-34-85 z załogami, skompletowanymi z młodych rosyjskich czołgistów z jednego z ośrodków zapasowych Armii Czerwonej. Ponadto w nocy 11/12 marca włączono w skład brygady 10 czołgów T-34-85 wraz z załogami i amunicją z 64 BPanc. Gw. ${ }^{85} \mathrm{O}$ ile maszyny przekazane 11 marca były fabrycznie nowe, a ich stan techniczny był bez zarzutu, to pojazdy z 64 BPanc. Gw. pozostawiały wiele do życzenia. Zastępca dowódcy brygady ds. polityczno-wychowawczych, mjr Adolf Bromberg ${ }^{86}$, zanotował: „Dnia $12.3 \mathrm{w}$ noc przed szturmem Wejherowa przybyło 10 czołgów przekazanych nam z 64 Brygady [Pancernej Gwardii]. Czołgi te mocno sfatygowane, wybrano najgorsze - z załogami specjalnie skompletowanymi z najsłabszych czołgistów[,] przydzielone zostały również do 3 batalionu. To uzupełnienie dopełniło zmiany oblicza Brygady. W czołgach załogi są w 90\% nowo[przybyłe] z Armii Czerwonej, oficerowie bez wyjątku nowoprzybyli z Armii Cz[erwonej]. Nowy kolektyw baonów czołgowych przybył do nas w uciążliwym marszu i z marszu poszedł do boju. Do ataku na Wejherowo poszły nowoprzybyłe czołgi 3 batalionu na 6 godzin przed atakiem. W tych warunkach sformowanie i zadomowienie nowoprzybyłych odbywało się powierzchownie i pospiesznie. Z każdą załogą

${ }^{83} 10$ III 1945 r. 1 BPanc Gw. liczyła 1269 oficerów i żołnierzy, a uzbrojona była w 28 czołgów T-34-85. Dodatkowe wzmocnienie stanowił 400 papanc. Gw. i dwie wyrzutnie rakiet M-13 „Katiusza”; ЦАМO, f. 3440, o. 1, d. 113, Выписка из журнала боевых действий 1 гв. тбр, b.m. 26 III 1945 r., k. 139.

${ }^{84}$ ЦАМО, f. 299, о. 3070, d. 610, Боевое донесение №103 штаба 8 гв. мк, Chynowie 12 III 1945 r., k. 163.

${ }^{85}$ Ibidem, d. 813, Журнал боевых действий штаба 1 гв. ТА, b.m. 9 V 1945 r., k. 119.

${ }^{86}$ Adolf Bromberg (ur. 1912 w Lublinie - zm. 1993 w Sztokholmie). Pochodził z rodziny żydowskiej. W okresie PRL wydawca książek o tematyce naukowej, encyklopedysta. Zaraz po zakończeniu wojny zmienił imię na Adam, najpewniej aby uniknąć przykrych skojarzeń Z wodzem III Rzeszy. Zob. T. Rutkowski, Adam Bromberg $i$ „encyklopedyści”. Kartka z dziejów inteligencji w PRL, Warszawa 2010, passim. 
przeprowadzono rozmowy wyjaśniające charakter naszej Armii, przełamywano niezadowolenie z przeniesienia i nieufność. Wśród załóg 64 Brygady [Pancernej Gwardii] rozpowszechnione było mniemanie, że jadą na paradę i twarda rzeczywistość bojowa zaskoczyła ich. Znaleźli się nawet tchórze, którzy uciekli do macierzystej Brygady gdy ich czołg został podbity" ${ }^{\text {" }}$.

Jak wynika z powyższego, odbudowa 1 BPanc. im. Bohaterów Westerplatte odbyła się kosztem stosunków narodowościowych panujących w jednostce. Fakt, że miało to miejsce w okresie podporządkowania jednostki sowieckim strukturom, z dala od pozostałych jednostek "ludowego” Wojska Polskiego, pozwalał na zamaskowanie tego wstydliwego faktu przed polskim społeczeństwem.

Do świtu 12 marca zmianie uległa sytuacja taktyczna wokół Wejherowa. Wieczorem 11 marca w rejon na południe od miasta podeszli żołnierze $40 \mathrm{KSG}$. pod dowództwem gen. mjr. Siergieja Gorochowa ${ }^{88}$. Pojawienie się tego dużego związku taktycznego zmieniło stosunek sił pod Wejherowem na korzyść Sowietów. Zaraz po przybyciu artyleria korpusu rozpoczęła ostrzał Wejherowa, a dywizje podjęły następujące działania:

102 DSGw. z rubieży linii kolejowej na odcinku Luzino-Gościcino wykonała natarcie na zalesione wzniesienia na południe od Wejherowa. Uporczywe walki prowadzone od południa do zmroku 11 marca umożliwiły dywizji opanowanie terenu do rejonu Nowego Dworu Wejherowskiego i leśniczówki Nowiny. W czasie boju meldowano o rozpoznaniu sił niemieckich w postaci dwóch kompanii piechoty, wspartych trzema działkami kal. $37 \mathrm{~mm}$ i baterią moździerzy. W wyniku starcia nieprzyjaciel miał stracić: 3 transportery opancerzone, 4 armaty i kolumnę 30 ciężarówek ${ }^{89}$. W toku całodziennych starć 102 DSGw. straciła 18 zabitych i 31 rannych. Pomimo poniesionych strat przeprowadzone natarcie przyniosło sukces w postaci oskrzydlenia Wejherowa od południa, co przekreślało niemieckie szanse na utrzymanie tej miejscowości ${ }^{90}$.

101 DSGw. przemieszczała się w centrum ugrupowania 40 KSGw. Dywizja maszerowała w dwóch rzutach wzdłuż szosy z Lęborka do Wejherowa, niszcząc po drodze grupy żołnierzy nieprzyjaciela w sile do kompanii piechoty,

${ }^{87}$ Centralne Archiwum Wojskowe Wojskowego Biura Historycznego (dalej: CAW-WBH), Zesp. 153: 1 Brygada Pancerna, sygn. III.253.124, Meldunek pol-wych [polityczno-wychowawczy], b.m. 7-8 III 1945 r., s. 58.

${ }^{88}$ А. С. Завьялов, Т. Е. Калядин, Восточно-померанская наступательная операция советских войск. Февраль-март 1945 г., Москва 1960, s. 179.

${ }^{89}$ ЦАМО, f. 1284: 102 гвардейская стрелковая дивизия (65 стрелковая дивизия) (dalej: f. 1284), о. 1, d. 41, Боевое донесение №52 штаба 102 гв. сд, Sopieszyno 12 III 1945 r., k. 107.

${ }_{90}^{9}$ ЦАМО, f. 917, о. 1, d. 160, Журналы боевых действий 102 гв. сд, b.m. 28 V 1945 r., k. 155 . 
które próbowały przedrzeć się do Gdyni. Przed zmrokiem 11 marca dywizja skoncentrowała się w rejonie Bolszewa i Gościcina ${ }^{91}$.

10 DSGw. zajęła pozycje na lewym skrzydle $40 \mathrm{KSGw}$. i skoncentrowała się w rejonie Paradyż-Zelewo, skąd przystąpiła do działań zaczepnych w rejonie na północ od Wejherowa w kierunku Małej Piaśnicy i Kąpina i dalej do wsi Połchowo. W toku walk dowództwo dywizji oceniło siły nieprzyjaciela na co najmniej dwie kompanie piechoty broniące się w na wcześniej przygotowanej pozycji obronnej, złożonej z dwóch linii okopów i licznych stanowisk ogniowych dla CKM. Całodzienny bój nie doprowadził do przełamania w kierunku Połchowa, jednak niemiecka obrona została nadwyrężona, co później przełożyło się na sukces $11 \mathrm{KPanc}$. Gw., który wykonał w tym rejonie uderzenie w kierunku Pucka. Podczas walki 8 żołnierzy 10 DSGw. zostało zabitych, a 18 rannych $^{92}$.

Atak na Wejherowo rozpoczął się 12 marca o godz. 5.30 od półgodzinnej nawały ogniowej, wykonanej przez artylerię 101 DSGw. i 79 Pułk Rakietowy Gw. ${ }^{93}$ Spadające pociski eksplodowały w centrum miasta. Pod ogniem znalazło się stanowisko dowodzenia 4 Batalionu Zapasowego SS ${ }^{94}$. W bezpośrednim uderzeniu na miasto wzięły udział: 19 BZmech. Gw., 1 BPanc. Gw., 1 BPanc. im. Bohaterów Westerplatte, 329 i 321 p. strz. Gw. ze 101 DSGw. W drugim rzucie znalazła się 20 BZmech. Gw., która otrzymała zadanie zdobycia Rumi-Janowa ${ }^{95}$. Walki trwały krótko. Wyjście sowieckich dywizji na północ i południe od Wejherowa wpłynęło na trwałość niemieckiej obrony dużo bardziej niż sowiecki ostrzał artyleryjski. Gdy rozpoczęło się natarcie, oddziały niemieckie były już $\mathrm{w}$ trakcie odwrotu ${ }^{96}$. W samym mieście nie

\footnotetext{
${ }^{91}$ Ibidem, Журнал боевых действий 101 гв. сд, b.m. 9 V 1945 r., k. 58-59.

92 Trudność $\mathrm{w}$ walce sprawiały niedostatki zaopatrzenia powodowane problemami w podciągnięciu tyłów i zaopatrzenia w rejonie walk, co wiązało się obecnością niemieckich uchodźców tarasujących drogi; ЦАМO, f. 1068: 10 гвардейская дивизия (dalej: f. 1068), o. 1, d. 84, Оперативная сводка №50 штаба 10 гв. сд, b.m. 11 III 1945 r., k. 89.
}

${ }^{93}$ http://www.nevskye.narod.ru/2_nevskyh/bykovsky.htm (dostęp 25 X 2018 r.).

${ }^{94}$ F. Husemann, Die guten Glaubens..., s. 508.

${ }_{95}$ ЦАМО, f. 46, о. 2394, d. 1379, Боевое донесение №259 штаба 1 гв. ТА, b.m. 12 III 1945 r., k. 32.

${ }^{96}$ Po zakończeniu walk o Wejherowo na ulice wyszli Polacy i zaczęli witać się z żołnierzami 1 BPanc. im. Bohaterów Westerplatte. W ciągu kolejnych godzin radosna atmosfera szybko ustąpiła trwodze. Zastępca dowódcy brygady ds. polityczno-wychowawczych, mjr Bromberg, zapisał: „Ludność miejscowa przyjmowała naszą brygadę serdecznie, mimo że wojska Czerwonej Armii obchodzą się [z cywilami] tak [okrutnie] jak z ludnością niemiecką[,] mają miejsce masowe wypadki gwałtów i rabunków nie wiedząc o tym że mimo wszystko jest to ludność polska i tereny polskie". CAW-WBH, Zesp. 153: 1 Brygada Pancerna, sygn. III.253.124, Meldunek pol-wych [polityczno-wychowawczy], b.m. 15 III 1945 r., s. 57. 
napotkano oporu, o czym świadczy fakt, że o godz. 12.00 do Wejherowa przybył gen. Driemow i zainstalował tu swój sztab ${ }^{97}$.

Po zajęciu Wejherowa ${ }^{98}, 12$ marca o godz. 10.00, 1 BPanc. im. Bohaterów Westerplatte oraz 19 BZmech. Gw. otrzymały zadanie opanowania z marszu Redy oraz Janowa ${ }^{99}$. Przy wyjeździe $z$ Wejherowa czołgi brygady dostały się pod rzadki ogień artylerii prowadzony ze wzgórz na północ od Śmiechowa, ale obyło się bez strat ${ }^{100}$. W samej dzielnicy czołgiści rozbili kolumnę niemieckich ciężarówek z zaopatrzeniem, należącą do 4 PDGPanc. SS ${ }^{101}$. Obie brygady szybko pokonały $8 \mathrm{~km}$ drogi z Wejherowa do Redy i bez zatrzymywania wjechały na ulice tego miasta. W Redzie walkę podjęła grupka żołnierzy uzbrojonych w Panzerfausty, jednak ich opór został szybko zdławiony ${ }^{102}$. Po południu pododdziały 1 BPanc. im. Bohaterów Westerplatte wjechały do wsi Biała Rzeka, położonej 2 km na zachód od Rumi, i niemal natychmiast dostały się pod silny ogień artyleryjski z rejonu wzgórz na południe od Redy i na zachód od Rumi. Ostrzał był tak silny, że pododdziały przeszły do obrony, nie podejmując tego dnia dalszych działań zaczepnych ${ }^{103}$.

${ }^{97}$ ЦАМО, f. 299, о. 3070, d. 610, Боевое донесение №104 штаба 8 гв. мк, Góra 12 III 1945 r., k. 164.

${ }^{98} \mathrm{~W}$ walkach o Wejherowo i Redę 19 BZmech. Gw. straciła 3 zabitych i 34 rannych żołnierzy. 101 DSGw. utraciła 29 żołnierzy zabitych i 84 rannych. Straty 1 BPanc. Gw. nie są znane, wiadomo jedynie, że jednostka nie utraciła żadnego ze swoich czołgów. 1 BPanc. im. Bohaterów Westerplatte straciła 13 zabitych i rannych oraz trzy czołgi uszkodzone; CAW-WBH, Zesp. 153: 1 Brygada Pancerna, sygn. III.253.53, Sprawozdanie o działaniach bojowych i formularz 1-ej Samodzielnej Polskiej Warszawskiej Brygady Pancernej imienia ВОН. Westerplatte - marzec 1945 r., b.m., s. 12; ЦАМО, f. 299, о. 3070, d. 704, Выписка из журнала боевых действий 19 гв. мбр, b.m. 2 V 1945 r., k. 95; f. 917, o. 1, d. 160, Журнал боевых действий 101 гв. сд, b.m. 9 V 1945 r., k. 59.

${ }^{99} \mathrm{~W}$ czasie wojny Janowo było odrębną miejscowością, współcześnie jest to największa dzielnica Rumi.

${ }^{100}$ K. Przytocki, Warszawska Pancerna: z dziejów 1 Warszawskiej Brygady Pancernej im. Bohaterów Westerplatte 1943-1946, Warszawa 1981, s. 232.

${ }^{101}$ F. Husemann, Die guten Glaubens..., s. 503.

102 Zbigniew Flisowski podaje na podstawie relacji anonimowego naocznego świadka, że w mieście zniszczono dwa działa przeciwpancerne oraz wyeliminowano $\mathrm{z}$ walki kilku żołnierzy uzbrojonych w granatniki typu Panzerfaust; Z. Flisowski, Pomorze: reportaż z pola walki, Warszawa 1978, s. 238.

${ }^{103}$ Pod koniec dn. 12 III 1945 r. 8 KZmech. Gw. zajmował następujące pozycje: 1 BPanc. Gw. skoncentrowała się we wschodniej części Wejherowa; 1 BPanc. im. Bohaterów Westerplatte i 19 BZmech. Gw. walczyły pod Białą Rzeką, Rumią i Janowem; 20 BPanc. Gw. przeszła do natarcia w kierunku wschodnim, lecz podobnie jak polska jednostka, została zatrzymana - $200 \mathrm{~m}$ na zachód od Janowa; 21 BZmech. Gw. przemieszczała się za 20 BPanc. Gw. w rejon Zbychowa, osłaniając tym samym działania korpusu od południa. ЦАМO, f. 299, о. 3070, d. 610, Боевое донесение №104 штаба 8 гв. мк, Góra 12 III 1945 r., k. 164. 
Po sześciu dniach nieustannych postępów terenowych jednostki 19 A i $8 \mathrm{KZmech}$. Gw. dotarły do głównej linii niemieckiego oporu. Od tego momentu działania wojenne w Pradolinie Redy-Łeby przybrały charakter pozycyjny.

W miarę zbliżania się do Bałtyku ukształtowanie terenu stwarzało coraz większe przeszkody dla działań zaczepnych. Na południe od Pradoliny Redy-Łeby rozciągał się obszar Pojezierza Kaszubskiego. Rzeźba terenu była tu mocno pofałdowana. Relief był znacznie silniejszy niż w rejonie Słupska i Lęborka, a mała rozległość wzniesień przy jednoczesnych różnicach $\mathrm{w}$ wysokości sprawiała wrażenie niewysokich gór. Wzgórza sięgały nawet do 140 m n.p.m. ${ }^{104}$ Ruch wojsk szybkich był tu możliwy tylko wzdłuż wąskich dróg, a te usytuowane są $\mathrm{w}$ dolinach pomiędzy wzniesieniami, co czyni je łatwymi do zablokowania. Lesistość terenu była znacząca, co również sprzyjało organizowaniu trwałej i skutecznej obrony.

Jako że Gdynia stanowiła dla Kriegsmarine strategicznie ważną bazę morską, sprawą wielkiej wagi stało się zabezpieczanie portu i stoczni przed napadem z powietrza. Jeszcze we wrześniu 1939 r. Niemcy przystąpili do fortyfikowania okolicznych wzgórz i budowy systemu stanowisk obrony przeciwlotniczej. Wraz ze zbliżaniem się frontu wschodniego do granic III Rzeszy zapadła decyzja zaadaptowania istniejącego systemu obrony plot. do warunków wojny lądowej. W efekcie powziętych prac powstał tzw. gdyński rejon umocniony. Trzonem niemieckiej obrony stały się już istniejące, ufortyfikowane stanowiska artylerii plot. zlokalizowane w: Kolibkach, Małym i Wielkim Kacku, Chwarznie, Łężycach, Zagórzu i na obszarze Kępy Oksywskiej ${ }^{105}$. Jednostką odpowiedzialną za obronę plot. Gdyni został sformowany we wrześniu 1942 r. 9 Morski Pułk Artylerii Przeciwlotniczej. W marcu 1945 r. pułk składał się czterech dywizjonów. Kluczową rolę w walce przeciwko 8 KZmech. Gw. i 1 BPanc. im. Bohaterów Westerplatte odegrał 259 morski dywizjon artylerii plot. dysponujący uzbrojeniem w postaci 16 armat SK C/32 kal. $105 \mathrm{~mm}$ i 12 Flak $36 \mathrm{kal} .88 \mathrm{~mm}^{106}$.

Po południu 12 marca działania zaczepne 1 BPanc. im. Bohaterów Westerplatte zatrzymały się pod ogniem czterech armat plot. kal. $105 \mathrm{~mm} \mathrm{z}$ baterii „Sagorsch”, która usytuowana była na dominującym nad Rumią i Janowem wzgórzu 90,5 o nazwie własnej Góra Markowca. Od 1942 r. załoga baterii „Sagorsch" ćwiczyła ostre strzelanie do tarcz o wymiarach $3 \times 4 \mathrm{~m}$, usypanych

${ }^{104}$ Studium geograficzno-przyrodnicze i ekonomiczne województwa gdańskiego, red. J. Moniak, Gdańsk 1974, s. 38.

105 B. Perzyk, Baterie przeciwlotnicze niemieckiej marynarki, 1937-1945, cz. II, „Archeologia Wojskowa” 1995, nr 6, s. 19.

${ }^{106}$ J. Jarosz, Artyleria nadbrzeżna polskiego wybrzeża, Gdynia 2018, s. 31-35, 92-105; B. Bölscher, Hitlers Marine im Landkriegseinsatz: Eine Dokumentation, Norderstedt 2015, s. 74. 
z białego piasku lub zrobionych z płótna i ustawionych na przedpolu Rumi i Janowa. W marcu 1945 r. bateria dysponowała pokaźnym zapasem amunicji ${ }^{107}$. Położone u podnóża Góry Markowca miejscowości Rumia, Janowo i Zagórze przekształcone zostały w punkty oporu. Zbudowano tu trzy linie okopów, uzupełnione czterema lub pięcioma drewniano-ziemnymi schronami na każdym kilometrze. Stanowiska karabinów maszynowych ulokowano w piwnicach murowanych domów. Aby polepszyć pole ostrzału, zburzono kilka pojedynczych budynków na zachód od Rumi. Od zachodu dostęp do Janowa blokował rów przeciwczołgowy, który przecinał prostopadle szosę Reda-Janowo. Pomiędzy zabudowaniami Rumi i Janowa ustawiono zapory przeciwpancerne i rozłożono miny ${ }^{108}$.

Niebagatelną rolę w przebiegu dalszych walk odegrała pozycja ogniowa na wzgórzu $162,5^{109}$, położnym $600 \mathrm{~m}$ na wschód od Łężyc. Węzeł obrony składał się ze stanowisk przygotowanych dla czterech armat plot. kal. $105 \mathrm{~mm}$, ustawionych na betonowych podstawach. Artyleria była usytuowana tak, by móc prowadzić skuteczny ostrzał celów naziemnych i powietrznych. W odległości $100 \mathrm{~m}$ od stanowisk armat stał żelbetonowy schron, w którym mieściło się centrum dowodzenia baterią. Schron mieścił dwie kazamaty, a jego ściany miały $20-40 \mathrm{~cm}$ grubości. Wokół rozstawiono lekkie armaty kal. $20 \mathrm{~mm}$. Ponadto na wzgórzu znajdowało się stanowisko dla reflektora plot. $\mathrm{z}$ pomieszczeniem dla generatora elektrycznego, żelbetonowy magazyn zaadaptowany do pełnienia roli punktu oporu, a także osiem ziemianek, które mogły pełnić zarówno rolę schronów bojowych, jak i drewniano-ziemnych punktów oporu. Każdą ziemiankę od góry zabezpieczały 3-4 warstwy drewnianych bali o grubości $25-30 \mathrm{~cm}$, dodatkowo przysypane $20-30 \mathrm{~cm}$ warstwą ziemi. Oprócz tego istniały lżejsze schrony, zbudowane z kłód grubości 12-15 cm. Wzgórze otoczone było 2-3 liniami okopów o pełnym profilu głębokości 0,6-1,1 m i szerokości 0,7 m, przed którymi rozstawiono zapory $\mathrm{z}$ drutu kolczastego, osadzonego na niskich drewnianych kołkach rozstawionych co 4-5 $\mathrm{m}$. Okopy były połączone z ziemiankami i schronem za pomocą rowów łącznikowych. Cały węzeł zajmował obszar o szerokości $800 \mathrm{~m}$ i głębokości do $600 \mathrm{~m}^{110}$.

Opisane powyżej węzły obrony były połączone pojedynczą (niekiedy podwójną) linią okopów, która biegła wzdłuż linii: Mały Kack-Witomino -Chwarzno-wzgórze 162,5-Zagórze-Reda. Linie okopów powiązane były między sobą siecią rowów łącznikowych. Wzdłuż okopów wzniesiono

\footnotetext{
${ }^{107}$ http://www.fortyfikacje.eksploracja.pl/fr_markowiec.htm (dostęp 22 III 2018 r.).

${ }^{108}$ F. Husemann, Die guten Glaubens..., s. 508-510.

${ }^{109} \mathrm{~W}$ źródłach sowieckich występuje pod oznaczeniem wzgórze 165,0.

${ }_{110}$ ЦАМО, f. 46, о. 2394, d. 1186, Краткая сводка обобщенного боевого опыта войск 19 A, b.m. 14 IV 1945 r., k. 79.
} 
stanowiska ogniowe armat ppanc. i plot. oraz karabinów maszynowych, które z reguły były wysunięte przed przedni skraj okopów. Z każdego punktu ogniowego można było wycofać się rowem łącznikowym do drewnianoziemnego schronu. Przedni skraj obrony wytyczono tak, aby przebiegał przez dominujące wzgórza i skraje masywów leśnych, co miało gwarantować możliwość prowadzenia ognia na duże odległości i uniemożliwiać skryte uderzenie nieprzyjaciela na tyły pozycji ${ }^{111}$.

W okresie działań odwrotowych od 6 do 13 marca 1945 r. 4 PDGPanc. SS utraciła 6 z 17 armat kal. $75 \mathrm{~mm}$. Czołg dowodzenia i działa szturmowe nie doznały uszczerbku i wciąż były gotowe do walki. W 7 DPanc. przywrócono do pełniej sprawności dwa czołgi dowodzenia i jedną Panterę, ale w wyniku walk stracono 5 armat ppanc., $743 \mathrm{dncz}$ posiadał już tylko 22 niszczyciele czołgów Jagdpanzer 38(t). Pod rozkazy dowódcy korpusu oddano 215 DP, która mogła wystawić 10 dział szturmowych StuG III i 10 armat ppanc. $75 \mathrm{~mm}^{112}$. Na rzecz jednostek korpusu działała Morska Dywizja Forteczna "Gotenhafen", sformowana z batalionów alarmowych, personelu morskiego i marynarzy. Dywizja nie posiadała sztabu ani jednostek tyłowych, toteż wchodzące w jej skład bataliony zostały podporządkowane dowódcom poszczególnych dywizji VII KPanc. ${ }^{113}$

Jednostki VII KPanc. zajęły pozycje obronne wzdłuż linii: Gdynia-Janowo-Rumia-Biała Rzeka (wył.)-grzbiet Kępy Oksywskiej-Rewa, w następującym szyku: odcinek Rewa-Mosty-Kazimierz broniony był przez Pułk Lotniczy „Witt” (dwa bataliony morskie i jeden sformowany z personelu Luftwaffe z lotniska wojskowego w Rumi). Na tyłach pułku w rejonie Dębogórza znajdowała się kompania piechoty z 7 pgpanc. SS z 4 PDGPanc. SS, która pełniła rolę odwodu; Rumi i Janowa broniły elementy 4 PDGPanc. SS: 4 batalion zapasowy SS, 8 pgpanc. SS i artylerzyści z 4 dplot SS walczący w roli piechoty; Szmeltę i Zagórze zajmował 7 pgpanc. SS z 4 PDGPanc. SS i trzy słabe bataliony Morskiej Dywizji Fortecznej „Gotenhafen”114.

Według zeznań jeńców, przesłuchiwanych w sztabie 1 APanc. Gw., w północnej części Janowa broniła się kompania alarmowa I batalionu z Brygady Zapasowej „Feldherrnhalle”115. W rejonie stacji kolejowej w Zagórzu i na południe od tejże miejscowości pozycje zajmował batalion zbiorczy 7 DPanc.

${ }^{111}$ Ibidem, k. 80.

${ }^{112}$ ЦАМО, f. 500, o. 12467, d. 28, Lagekarte der Heeresgruppe „Weichsel”, b.m. 11 III 1945 r., k. 1 .

${ }^{113}$ S. W. Mitcham jr., Dywizje strzeleckie i lekkie. Ordre de Bataille, tłum. R. Michulec, Warszawa 2010, s. 209-211.

${ }^{114}$ F. Husemann, Die guten Glaubens..., s. 511-513.

${ }^{115}$ Według zeznań jeńców Brygada Zapasowa „Feldherrnhalle” została sformowana w dniu 9 III 1945 r. w Gdańsku i liczyła 250 oficerów i żołnierzy; ЦАMO, f. 299, o. 3070, d. 792, 
w składzie trzech kompanii, liczących po 120 żołnierzy, którzy wycofali się ze Słupska ${ }^{116}$. Pod Łężycami w lesie pomiędzy Zagórzem a Cisowem i Pustkami Cichowskimi do rejonu Witomina pozycje utrzymywali piechurzy z następujących jednostek: 94 i 96 Pułków Piechoty (pp) z 32 DP, 390 pp z 215 DP, 103 morskiego batalionu strzelców Morskiej Dywizji Fortecznej "Gotenhafen”. Rolę odwodu spełniały działa szturmowe, z których sformowano jednostkę o sile wzmocnionej kompaniii ${ }^{117}$.

Zgodnie z rozkazami gen. Katukowa $8 \mathrm{KZmech}$. Gw. miał opanować Gdynię wraz z portem i wyjść nad brzeg Morza Bałtyckiego na odcinku do Żelistrzewa. Odległość z Redy do portu w Gdyni wzdłuż szosy biegnącej Pradoliną Redy-Łeby wynosiła jedynie $15 \mathrm{~km}$. Jednocześnie $3 \mathrm{KPanc}$. Gw. wykonywał uderzenie w kierunku Orłowa. Gdyby oba sowieckie korpusy wykonały postawione zadania, to siły niemieckie broniące Gdyni znalazłyby się w krytycznym położeniu - okrążone, bez możliwości ewakuacji drogą morską. Dodatkowo, wykonując ruch Pradoliną Redy-Łeby, 8 KZmech. Gw. odcinał Kępę Oksywską od Gdyni, tworząc podstawę do dalszego natarcia w kierunku Oksywia.

Bój o przełamanie niemieckich pozycji na rubieży Rumia-Janowo-Zagórze oraz na Górze Markowca wznowiono 13 marca i trwał on do 16 marca. W walki zaangażowano 1 BPanc. im. Bohaterów Westerplatte, 19 i $20 \mathrm{BZmechGw.} \mathrm{i} \mathrm{całą} 101 \mathrm{DSGw}$.

Pomimo kilkakrotnych ataków, podejmowanych zarówno w dzień, jak i w nocy, każda próba przełamania niemieckiej pozycji kończyła się niepowodzeniem. Białą Rzekę od Janowa oddzielał rów przeciwczołgowy, zaś na skraju Janowa wzniesiono zapory przeciwpancerne i ułożono pola minowe. Wymienione przeszkody powodowały, że działania czołgów były wyjątkowo trudne, szczególnie biorąc pod uwagę, że odbywały się pod ogniem przeciwpancernym ze stanowisk na Górze Markowca. W czasie walk prowadzonych 13 marca 3 batalion 1 BPanc. im. Bohaterów Westerplatte znalazł się pod tak silnym ostrzałem, że nad jednostką zawisła groźba całkowitego zniszczenia. Czołgi zdołały wycofać się spod ognia tylko dlatego, że jeden z nich, trafiony odłamkiem w zbiornik z olejem, zaczął mocno dymić, co umożliwiło batalionowi wycofanie się w kierunku pozycji wyjściowych pod osłoną dymu ${ }^{118}$. Uderzenia broni pancernej nie mogły być efektywne, gdyż piechota

Развединформация о действиях противника на Гдынском направлении №36, штаба 1 гв. ТА, b.m. 18 III 1945 r., k. 358-359.

${ }^{116}$ Według zeznań jeńców jednostką miał dowodzić doświadczony oficer odkomenderowany z 7 DPanc; ibidem.

${ }^{117}$ Czołgiści i personel 7 Pułku Pancernego 7 DPanc., dla których zabrakło sprzętu pancernego, trafili do oddziałów liniowych, walcząc w roli piechoty; ibidem.

${ }^{118}$ K. Przytocki, Warszawska Pancerna..., s. 237. 
101 DSGw. nie zdołała zniszczyć niemieckiej baterii ze względu na głęboko urzutowaną obronę u podnóży wzgórza. Tylko 13 marca 20 BZmech. Gw. i 326 p. strz. Gw. przełamały osiem linii niemieckich okopów w lesie $400 \mathrm{~m}$ na południowy-zachód od Janowa, a i tak dalsze postępy okazały się niemożliwe wskutek kontrataku czołgów 7 DPanc. W walkach piechota ponosiła duże straty, zwłaszcza od pocisków artyleryjskich rozrywających się wśród koron drzew ${ }^{119}$. Obrońcy wspierani byli przez ogień artylerii pokładowej z ciężkich krążowników „Lützow” i „Prinz Eugen”, operujących na wodach Zatoki Gdańskiej ${ }^{120}$. Na skutek tego ostrzału wszystkie zabudowania Białej Rzeki zostały zniszczone. Ostrzał paraliżował ruch za dnia i mocno utrudniał przygotowania do kolejnych ataków ${ }^{121}$.

Pod koniec 15 marca 1 BPanc. im. Bohaterów Westerplatte dysponowała 16 zdolnymi do walki czołgami z 35 posiadanych przed bojem o Wejherowo ${ }^{122}$. Kolejne trzy T-34-85 przywrócono do gotowości bojowej w bazie remontowej pod Zelewem, lecz nie zdążyły one dojechać pod Janowo ${ }^{123}$. Zniszczeniu uległy wszystkie czołgi przekazane z 64 BPanc. Gw. W czasie walk 14 marca, rosyjska załoga jednego z tych czołgów porzuciła unieruchomiony pojazd i zdezerterowała $\mathrm{z}$ pola walki w rejon rozlokowania $8 \mathrm{KZmech}$. Gw. ${ }^{124}$

Dowództwa $40 \mathrm{KSGw}$. i 19 A dostrzegały trudną sytuację, w jakiej znalazł się $8 \mathrm{KZmech}$. Gw. W czasie gdy trwały walki o Janowo i Rumię, 10 DSGw. ześrodkowała się na północ od Redy. W myśl rozkazów 40 KSGw. dywizja wykonała marsz w kierunku północno-wschodnim, wychodząc nad Bałtyk w rejonie Mrzezina i Rewy, skąd piechota miała wykonać zwrot i uderzyć na południe, wychodząc na Kępę Oksywską. Manewr miał doprowadzić do obejścia węzła obrony Rumia-Janowo-Zagórze od północy i wschodu. Gdy piechota 10 DSGw. wymaszerowała w kierunku Rewy, okazało się, że Niemcy spiętrzyli liczne kanały i strumienie w okolicy, zalewając grząskie torfowiska, co uniemożliwiło rozwinięcie pułków w polu. Pomimo niekorzystnych warunków zdecydowano o przeprowadzeniu rozpoznania tego kierunku. Zadanie to otrzymał batalion 28 p. strz. Gw. Korzystając z wąskich grobli,

${ }^{119}$ ЦАМО, f. 3336: 20 гвардейская механизированная бригада, о. 1, d. 36, Выписка из журнала боевых действий 20 гв. мбр, b.m. 31 III 1945 r., k. 46.

${ }^{120}$ CAW-WBH, Zesp. 153: 1 Brygada Pancerna, sygn. III.253.50, Meldunek bojowy batalionu fizylierów zmotoryzowanych, Reda 14 III 1945 r., s. 6; Meldunek rozpoznawczy №015 sztabu 8 KZmech. Gw. z dnia 13 III 1945 r., b.m., s. 22.

${ }^{121}$ Ibidem, sygn. III.253.53, Wyciąg z „Dziennika działań bojowych” BZF za msc. Marzec, b.m. [1945 r.], s. 80 .

${ }^{122}$ Ibidem, sygn. III.253.50, Meldunek o stratach 3 Bat.Cz., b.m. 16 III 1945 r., s. 30.

${ }^{123}$ Ibidem, Meldunek bojowy №09 sztabu 1 BPanc., b.m. 15 III 1945 r., s. 15.

${ }^{124}$ Ibidem, sygn. III.253.50, Meldunek 3 Bat.Cz., Reda 16 III 1945, k. 27; sygn. III.253.124, Meldunek pol-wych, b.m. 7-28 III 1945 r., s. 58. 
sowieccy piechurzy podeszli pod wieś Kazimierz, ale szybko dosięgnął ich ogień broni maszynowej prowadzony ze stoków Kępy Oksywskiej. Okazało się, że Kazimierz jest ufortyfikowany i stanowi ważny węzeł oporu w linii fortyfikacji polowych okalających Kępę Oksywską ${ }^{125}$. W rejon Kazimierza wyszły także poddziały 11 KPanc. Gw., które 12 marca zdobyły Puck, ale nie włączyły się do walk.

Po stwierdzeniu, że obszar Kępy Oksywskiej jest silnie broniony, dowództwo $40 \mathrm{KSGw}$. zaniechało wykonania manewru okrążającego, aby nie angażować sił w walki, które, ze względu na cechy terenu, strona niemiecka mogła prowadzić niezależnie od tych w Pradolinie Redy-Łeby.

12 marca dowódca $8 \mathrm{KZmech}$. Gw. podjął decyzję, która zaważyła na całokształcie walk prowadzonych w kolejnych dniach. Ze względu na fakt, że obszar Pradoliny Redy-Łeby był zbyt wąski, by skupić tu całość $8 \mathrm{KZmech}$. Gw., dowódca postanowił podzielić siły. 21 BZmech. Gw. i 1 BPanc. Gw. otrzymały rozkaz natarcia z rejonu Łężyc i Rogulewa w kierunku Chyloni, co umożliwiłoby przecięcie linii odwrotu wojsk niemieckich walczących pod Janowem i Rumią. Przegrupowanie brygad odbywało się powoli ze względu na roztopy i zły stan sieci drożnej. Do godz. 11.0013 marca 21 BZmech. Gw. dotarła do wsi Łężyce i Rogulewo, gdzie została zatrzymana kontratakiem niemieckiej piechoty wspartej bronią pancerną. Wkrótce w rejon ten dotarł 316 p. strz. Gw. ze 102 DSGw. Ponowiony atak obu jednostek doprowadził do opanowania obydwu wymienionych wsi. Dalsze działania zaczepne 316 p. strz. Gw. zostały zablokowane silnym ostrzałem z rejonu wzgórza 162,5, którego bronił 96 pp z 32 DP. Również 21 BZmech. Gw. zaniechała natarcia, ograniczając się do rozpoznania drogi wiodącej w kierunku Chyloni. Do końca dnia w rejon Rogulewa przybyły kolejne jednostki 102 DSGw.: w lukę pomiędzy 20 a 21 BZmech. Gw. wszedł 318 p. strz. Gw., podczas gdy 314 p. strz. Gw., artyleria i pododdziały wsparcia skoncentrowały się w rejonie wsi Reszki. Stanowisko dowodzenia 102 DSGw. urządzono w Nowym Dworze Wejherowskim. Dywizja otrzymała od dowództwa 40 KSGw. zadanie wyparcia nieprzyjaciela ze wzgórz położonych pomiędzy wsią Łężyce a Chylonią - dzielnicą Gdyni. Sowieccy dowódcy nie zdawali sobie sprawy, że podobnie jak pod Janowem, teren w rejonie Łężyce-Rogulewo został przygotowany do uporczywej obrony i został obsadzony przez jednostki $32 \mathrm{DP}$, wspartej przez działa szturmowe 7 DPanc. ${ }^{126}$

W wyniku opisanych powyżej przegrupowań ukształtował się 15-kilometrowy odcinek frontu, na którym $8 \mathrm{KZmech}$. Gw. i $40 \mathrm{KSGw}$. próbowały

${ }^{125}$ ЦАМО, f. 1068, о. 1, d. 88, Журнал боевых действий 10 гв. сд, b.m. 5 IV 1945 r., k. 33-34.

${ }^{126}$ ЦАМО, f. 1284, о. 52821, d. 1, Боевое распоряжение №36 штаба 102 гв. сд, №wy Dwór Wejherowski 13 III 1945 r., k. 161. 
dokonać przełamania niemieckiej obrony. Ze względu na ukształtowanie terenu działania zaczepne związków szybkich mogły być prowadzone po dwóch osiach: na prawym skrzydle - $\mathrm{z}$ rejonu Rogulewa w kierunku Chyloni, i na lewym - z linii Rumia-Janowo wzdłuż szosy w kierunku Gdyni. Zalesiony obszar, o powierzchni $20 \mathrm{~km}^{2}$, rozdzielający dwie wymienione osie natarcia, miał zostać zdobyty przez piechotę $40 \mathrm{KSGw}$.

1 BPanc. Gw. (23 T-34-85) wraz z 400 papanc. Gw. (5 SU-85) i 358 Pułkiem Artylerii Plot. przybyła do Rogulewa o świcie 14 marca ${ }^{127}$. Czołgiści otrzymali rozkaz wspierania piechoty $21 \mathrm{BZmech}$. Gw. w natarciu. Obie jednostki przeszły do działań zaczepnych o godz. 12.20, atakując niemieckie okopy na północ od Rogulewa. Gęsty las, wzdłuż którego biegł przedni skraj niemieckiej obrony, wykluczał możliwość rozwinięcia czołgów 1 BPanc. Gw. w szykach piechoty. Z tego względu brygada ugrupowała swoje maszyny w kolumnę wzdłuż drogi do Chyloni. Po dwóch godzinach walki piechota opanowała jedynie pierwszą linię okopów wzdłuż skraju lasu, a czołgi stoczyły pojedynek z wozami bojowymi nieprzyjaciela, które blokowały szosę na Chylonię ${ }^{128}$. W tym samym czasie czołgi 1 BPanc. Gw. dojechały do samotnego domu leśnika $-2,5$ km na północny wschód od Rogulewa ${ }^{129}$. Ruch kolumny pancernej był bardzo powolny. Droga była zablokowana zawałami leśnymi, barykadami ze zniszczonych pojazdów oraz minami. Każde podejrzane miejsce należało sprawdzić. Poruszający się przed czołgami saperzy zebrali 206 min - co oznacza, że na odcinek $1 \mathrm{~km}$ drogi przypadały 34 miny $^{130}$.

Przez całą noc 14/15 marca kolumna 1 BPanc. Gw. i 400 papanc. Gw. stała wzdłuż szosy przy domu leśnika. Rano 15 marca, w czasie przygotowań do walki, kolumna została ostrzelana przez nieprzyjacielską piechotę, ukrytą w lesie. Dzięki osłonie fizylierów i piechurów z 21 BZmech. Gw. atak odparto bez strat własnych. Działania zaczepne podjęto 15 marca o godz. 9.00. Po krótkim przygotowaniu artyleryjskim czołgi pod osłoną piechoty $21 \mathrm{BZmech}$. Gw. ruszyły do kolejnego ataku w kierunku Chyloni. Tak jak poprzednio, postępy były bardzo powolne. Do godz. 16.00 zgrupowanie osiągnęło rejon Marszewa $-1,3 \mathrm{~km}$ od pozycji wyjściowych ${ }^{131}$. Tutaj fizylierzy brygady zor-

${ }^{127}$ Po przybyciu do Rogulewa 358 Pułk Artylerii Plot. Gw. przeszedł do obrony. Armaty plot. ustawiono w lesie na południe od wsi, po obu stronach szosy w stronę Koleczkowa. Jednostka nie brała udziału w dalszym natarciu w kierunku Chyloni; ЦАMO, f. 299, o. 3070, d. 650, Боевое донесение штаба 358 гв. зенап №105, Rogulewo 14 III 1945 r., k. 111.

${ }^{128}$ ЦАМО, f. 3440, о. 1, d. 113, Выписка из журнала боевых действий 1 гв. тбр, b.m. 26 III 1945 r., k. 141.

${ }^{129}$ Obecnie znajduje się tu Leśny Ogród Botaniczny Marszewo.

${ }^{130}$ ЦАМО, f. 46, о. 2394, d. 1186, Краткая сводка обобщенного боевого опыта войск 19 A, b.m. 14 IV 1945 r., k. 84.

${ }^{131}$ Niewielka osada leśna w granicach Gdyni, leżąca na terenie dzielnicy Pustki CisowskieDemptowo. Zlokalizowana w Trójmiejskim Parku Krajobrazowym, rozciąga się wzdłuż 
ganizowali obronę okrężną, gdyż Niemcy wyprowadzili szereg kontrataków, licząc na możliwość zniszczenia sowieckich czołgów, stojących w ciasnym rzędzie wzdłuż szosy. Nocą z 15 na 16 marca niemieckie kontrataki nie ustawały, powtarzając się co 2-3 godziny. Różnica w wysokości pomiędzy drogą a wzniesieniami była jeszcze większa niż pod Rogulewem, co uniemożliwiało jakikolwiek manewr broni pancernej ${ }^{132}$. Wobec braku powodzenia 1 BPanc. Gw. przeszła do obrony. Po południu 16 marca w rejon Marszewa przybyli żołnierze $21 \mathrm{BZmech}$. Gw., lecz ich próby przejścia do działań zaczepnych nie przyniosły żadnych rezultatów. Droga do Gdyni od strony Rogulewa okazała się zamknięta ${ }^{133}$.

W dniach od 13 do 16 marca 8 KZmech. Gw. stracił 188 zabitych i 822 rannych, 13 czołgów T-34-85 zniszczonych i 12 uszkodzonych, 1 uszkodzone działo pancerne SU-76M i 2 armaty ${ }^{134}$.

Równolegle do walk prowadzonych przez $8 \mathrm{KZmech}$. Gw. działania wspierające prowadził $40 \mathrm{KSGw}$. Jak już wspomniano, na prawym skrzydle tego korpusu 102 DSGw. próbowała otworzyć drogę na Chylonię w rejonie Rogulewa i Łężyca, zaś na lewym 101 DSGw. walczyła pod Janowem i Zagórzem. 10 DSGw. w dniach 12-15 marca przebywała w rejonie Redy jako drugi rzut korpusu, rozpoznając rejon Kazimierza. W wyniku niekorzystnego przebiegu działań pod Rumią dywizja została skierowana do walki w rejon wsi Szmelta i Janowa ${ }^{135}$. Nie wpłynęło to jednak na powodzenie dalszych walk.

Walki prowadzone w dniach od 13 do 16 marca przez dywizje $40 \mathrm{KSGw}$. zakończyły się niepowodzeniem. Nie udało się zlikwidować niemieckich węzłów obrony na Górze Markowca i wzgórzu 162,5, które strzegły dostępu do Gdyni od północy i zachodu. Ponawiane każdego dnia natarcia poprzedzane były 15-30 minutowym przygotowaniem artyleryjskim ze strony artylerii dywizyjnej i pułkowej. Skuteczność tego ostrzału była mocno ograniczona, gdyż podczas bombardowania artyleryjskiego obrońcy wzgórz chronili się w licznych drewniano-ziemnych schronach, a zalesiony teren utrudniał korygowanie ognia. Wsparcie własnej piechoty w czasie trwającej już walki również okazało się problematyczne, ponieważ niosło zagrożenie porażenia własnych żołnierzy. Intensywny charakter walk wiązał się z dużym

drogi Gdynia Chylonia-Koleczkowo (ul. Marszewska) na odcinku ok. 3 km.

${ }_{132}$ ЦАМО, f. 3440, о. 1, d. 113, Выписка из журнала боевых действий 1 гв. тбр, b.m. 26 III 1945 r., k. 140.

${ }^{133}$ ЦАМО, f. 299, о. 3070, d. 610, Боевое донесение №111 штаба 8 гв. мк, Wejherowo 16 III 1945 r., k. 193.

${ }^{134}$ Bez strat poniesionych przez 1 BPanc. im Bohaterów Westerplatte. ЦАMO, f. 299, о. 3070, d. 610, Боевое донесение №103 штаба 8 гв. мк, Chynowie 12 III 1945 r., k. 173.

${ }^{135}$ ЦАМО, f. 917, о. 1, d. 186, Оперативная сводка №55 штаба 10 гв. сд, b.m. 16 III 1945 r., k. 196. 
zużyciem amunicji. Zaopatrzenia nie można było dostarczać wystarczająco szybko, gdyż brakowało materiałów pędnych dla ciężarówek, a transport $\mathrm{w}$ znacznym stopniu realizowano $\mathrm{z}$ wykorzystaniem zaprzęgów konnych. $\mathrm{W}$ efekcie następujące po sobie natarcia piechoty traciły impet na kolejnych liniach niemieckich okopów. Niemcy często przechodzili do kontrataków, odbijając $\mathrm{z}$ trudem zajęte pozycje, które następnego dnia trzeba było zdobywać jeszcze raz ${ }^{136}$.

W toku działań prowadzonych od 12 do 18 marca 1945 r. 10, 101 i 102 DSGw. poniosły straty w wysokości 2981 ludzi, w tym: 711 zabitych, 2127 rannych, 78 obłożnie chorych i 65 zaginionych. Szczegóły przedstawia tabela:

Tabela 1. Straty 10, 101 i 102 DSGw. w dniach 12-18 marca 1945 r.

\begin{tabular}{|c|c|c|c|c|c|c|c|c|c|c|c|c|}
\hline & \multicolumn{4}{|c|}{$\begin{array}{c}10 \text { Dywizja Strzelecka } \\
\text { Gwardii }\end{array}$} & \multicolumn{4}{|c|}{$\begin{array}{c}101 \text { Dywizja Strzelecka } \\
\text { Gwardii }\end{array}$} & \multicolumn{4}{|c|}{$\begin{array}{c}102 \text { Dywizja Strzelecka } \\
\text { Gwardii }\end{array}$} \\
\hline & zabici & ranni & chorzy & razem & zabici & ranni & $\begin{array}{l}\text { zagi- } \\
\text { nieni }\end{array}$ & razem & zabici & ranni & chorzy & razem \\
\hline 12.03 & 3 & 4 & 0 & 7 & 29 & 84 & 0 & 113 & \multirow{3}{*}{39} & \multirow{3}{*}{84} & \multirow{3}{*}{31} & \multirow{3}{*}{154} \\
\hline 13.03 & 0 & 46 & 3 & 49 & \multirow{2}{*}{107} & \multirow{2}{*}{415} & \multirow{2}{*}{14} & \multirow{2}{*}{536} & & & & \\
\hline 14.03 & 17 & 20 & 0 & 37 & & & & & & & & \\
\hline 15.03 & 17 & 37 & 0 & 54 & 76 & 130 & 0 & 206 & 31 & 89 & 6 & 126 \\
\hline 16.03 & 16 & 83 & 0 & 99 & 65 & 286 & 39 & 390 & 38 & 148 & 11 & 197 \\
\hline 17.03 & 9 & 39 & 0 & 48 & 11 & 32 & 0 & 43 & \multirow{2}{*}{143} & \multirow{2}{*}{289} & \multirow{2}{*}{27} & \multirow{2}{*}{459} \\
\hline 18.03 & 49 & 94 & 0 & 143 & 61 & 247 & 12 & 320 & & & & \\
\hline Łącznie & 111 & 323 & 3 & 437 & 349 & 1194 & 65 & 1608 & 251 & 610 & 75 & 936 \\
\hline
\end{tabular}

Źródło: opracowanie własne na podstawie: ЦАMO, f. 917, o. 1, d. 160, Журнал боевых действий 101 гв. сд, b.m. 9 V 1945 r., k. 59-64; f. 1284, o. 1, d. 46, Журнал боевых действий 102 гв. сд, b.m. 2 V 1945 r., s. 69-76; f. 1068, o. 1, d. 84, Оперативная сводка №51-58 штаба 10 гв. сд, b.m. 12-19 III 1945 r., k. 91-103

Niepowodzenie 8 KZmech. Gw. w Pradolinie Redy-Łeby wymusiło wprowadzenie do walki o Gdynię reszty 1 APanc. Gw., czego początkowo nie planowa$\mathrm{no}^{137}$. Rano 16 marca ustny rozkaz w tej sprawie wydał sam marsz. Rokossowski,

${ }^{136}$ ЦАМО, f. 917, о. 1, d. 160, Журнал боевых действий 102 гв. сд, b.m. 5 IV 1945 r., k. 158.

${ }^{137}$ Walki 11 KPanc. Gw. w dniach 11-16 III 1945 r. miały następujący przebieg: do rana 10 III 1945 r. 11 KPanc. Gw. przegrupował się przez Słupsk, a następnie z rejonu Główczyc wykonał uderzenie w kierunku Wicka, forsując rz. Łebę. We wsi Żelazno nastąpił podział sił korpusu. Jedna z brygad wraz z pododdziałami wsparcia wykonała uderzenie przez Choczewo w kierunku na Wierzchucino, tak aby objechać Jezioro Żarnowieckie od północy. Silny ogień artylerii niemieckiej broniącej odcinka rzeki Piaśnicy udaremnił ten manewr. Siły główne korpusu przejechały drogą przez Mierzyno i Kostkowo do Rybna, skąd planowano uderzyć w kierunku Pucka. 11 marca 11 KPanc. Gw. zdobył wieś Wielka Piaśnica, sforsował rz. Piaśnicę i uderzył w kierunku Pucka. Miasto zostało opanowane 
polecając dowódcy $11 \mathrm{KPanc}$. Gw. przegrupować korpus wraz z jednostkami wsparcia w rejon: Nowy Dwór Wejherowski-Bieszkowice-Koleczkowa. Rozkaz miał zostać wykonany do godz. 0.00 $0^{138}$. 11 KPanc. Gw. liczył 147 czołgów i dział pancernych ${ }^{139}$. Pojawienie się kolejnego związku pancernego zmieniło stosunek sił w broni pancernej pomiędzy jednostkami sowieckimi a niemieckimi na 4:1. Decyzja marsz. Rokossowskiego o wprowadzeniu do walki 11 KPanc. Gw. stanowi koniec walk w Pradolinie Redy-Łeby, a jednocześnie jest to początek zmagań o Gdynię, które potrwały do 27 marca $^{140}$.

W związku z brakiem widoków na uzyskanie przełamania pod Rumią $11 \mathrm{KPanc}$. Gw. został skierowany w rejon działania $134 \mathrm{KS}^{141}$. Następnie przy współdziałaniu z piechotą korpus przełamał niemieckie pozycje w Wielkim Kacku $^{142}$ i wykonał uderzenie w kierunku Redłowa. Dla strony sowieckiej było to rozwiązanie niekorzystne, ponieważ oznaczało konieczność prowadzenia natarcia $\mathrm{w}$ terenie zurbanizowanym $\mathrm{z}$ południowych przemieść miasta w kierunku północnym, gdzie zlokalizowany był port, przy czym zabudowa Gdyni jest rozłożona południkowo wzdłuż brzegów Morza Bałtyckiego. Ponadto przełamanie dokonane w Pradolinie Redy-Łeby dawałoby szansę na odcięcie Kępy Oksywskiej od portu w Gdyni, zaś natarcie wyprowadzone z Wielkiego Kacka umożliwiło nieprzyjacielowi wycofanie się z Gdyni na Kępę Oksywską, gdzie kontynuował on opór do 4/5 IV 1945 r. - do momentu ewakuacji większości sił drogą morską ${ }^{143}$.

12 III 1945 r. Pododdziały korpusu rozpoczęły oczyszczanie rejonu z sił nieprzyjaciela, oczekując jednocześnie na piechotę 19 A, która pozostała daleko w tyle za jednostkami szybkimi. W toku kolejnych dni jednostki korpusu podjęły próbę zniszczenia jednostek niemieckich broniących Półwyspu Helskiego, jednak poza zdobyciem Władysławowa zadania tego nie udało się wykonać. Niepowodzeniem zakończyła się także próba wsparcia działań $8 \mathrm{KZmech}$. Gw. poprzez uderzenie przez wieś Kazimierz na Kępę Oksywską. Podobnie jak to miało w miejsce w przypadku próby podjętej przez 10 DSGw., trudny teren i silna obrona nieprzyjaciela uniemożliwiały dokonanie przełamania tej pozycji. ЦАМO, f. 299, o. 3070, d. 759, Доклад о боевых действиях 1 гв. ТА, b.m. 23 V 1945 r., s. 29-34.

138 Ibidem; А. Х. Бабаджанян, Дороги победы, Москва 1975, s. 260.

${ }^{139}$ Stan na 18 III 1945 r. bez uwzględnienia 1 Brygady Pancernej im. Bohaterów Westerplatte; ЦАМО, f. 299, о. 3070, d. 578, Выписка из журнала боевых действий 11 гв. тк за период с 27 февраля по 26 марта 1945 г., b.m. 3 IV 1945 r., k. 127.

${ }^{140} 11$ KPanc. Gw. został wycofany z walki 26 III 1945 r.; ЦАМО, f. 299, о. 3070, d. 743, Доклад о боевых действиях 1 гв. ТА, b.m. 23 V 1945 r., k. 35-37.

${ }^{141}$ Po zdobyciu Kołobrzegu przez jednostki 1 Armii Wojska Polskiego 134 KS przegrupował się w rejon Gdyni.

${ }^{142} 17$ III 1945 r. 1 BPanc. im. Bohaterów Westerplatte wyszła z podporządkowania 8 KZmech. Gw. i przeszła pod komendę dowódcy 11 KPanc. Gw.

${ }^{143}$ K. Anduła, Udział 1 Warszawskiej Brygady Pancernej im. Bohaterów Westerplatte w walkach o Kępę Oksywska (30 marca-5 kwietnia 1945 r.), „Przegląd Historyczno-Wojskowy” 
W okresie bitwy o Gdynię od 16 do 26 marca $11 \mathrm{KPanc}$. Gw. poniósł straty: 79 zabitych i 229 rannych, 20 czołgów zniszczonych, a 21 uszkodzonych, 2 zniszczone działa pancerne i 2 kolejne uszkodzone ${ }^{144}$. Dla porównania w okresie od 8 do 15 marca, gdy 11 KPanc. Gw. wykonywał pierwotne zadanie (zdobycie Pucka), poniesione straty były mniejsze: 20 zabitych i 163 rannych, 3 czołgi zniszczone, 1 uszkodzone działo pancerne i 1 uszkodzona armata kal. $76 \mathrm{~mm}^{145}$. Podsumowując, w okresie od 1 do 28 marca 1 APanc. Gw. straciła: 1132 zabitych i 3834 rannych, 98 czołgów i 19 dział pancernych bezpowrotnie zniszczonych, 5 zniszczonych dział i dwie spalone wyrzutnie rakiet $^{146}$. Zdecydowana większość strat została poniesiona podczas bitwy w Pradolinie Redy-Łeby i w Gdyni. Szczególnie dotkliwe były straty w czołgach, które wyniosły $24,5 \%$ stanu wyjściowego armii, oraz straty w działach pancernych plasujące się na poziomie $13,3 \%$ stanu początkowego. Należy podkreślić, że statystyka strat $\mathrm{w}$ broni pancernej byłaby wielokrotnie większa, gdyby uwzględnić pojazdy uszkodzone, jednak te bardzo szybko powracały do linii po dokonaniu remontów. Na korzyść Sowietów działał fakt, że kontrolowali oni teren, na którym toczyły się walki, dlatego możliwe było ściąganie uszkodzonych pojazdów do baz remontowych ${ }^{147}$. Straty w składzie osobowym wyniosły $14 \%$ stanu wyjściowego armii.

\section{Podsumowanie}

Przebieg działań bojowych w Pradolinie Redy-Łaby świadczy o tym, że dowództwo 2 F. Biał. oraz 1 APanc. Gw. i 19 A niepoprawnie odczytało intencje strony niemieckiej. Działania wojenne, jakie rozegrały się w dniach od 6 do 12 marca 1945 r., miały charakter pościgu operacyjnego za nieprzyjacielem uchylającym się od rozstrzygającej bitwy. Nie potwierdziły się obawy marsz. Rokossowskiego - wycofujące się oddziały niemieckiej 2 A nie zamierzały organizować stałej obrony na linii rzeki Łupawy. Można przypuszczać, że szybki odwrót niemieckiej 2 A zaskoczył dowódcę 2 F. Biał.

2012, nr 3 (241), s. 43-62.

${ }^{144}$ ЦАМО, f. 299, о. 3070, d. 578, Выписка из журнала боевых действий 11 гв. тк за период с 27 февраля по 26 марта 1945 г., b.m. 3 IV 1945 r., k. 138.

${ }^{145}$ Ibidem, k. 125.

146 Ibidem, d. 759, Доклад о боевых действиях 1 гв. ТА, b.m. 23 V 1945 r., s. 58.

${ }^{147}$ Dla przykładu: na początku marca 19 A posiadała w jednostkach wsparcia 105 czołgów ciężkich i dział pancernych. Do końca wojny bezwzględna liczba wozów zniszczonych lub uszkodzonych wyniosła 96 pojazdów - czyli 91,4\% stanu wyjściowego. W okresie 24 II 9 V 1945 r. 274 Ruchoma Baza Remontu Czołgów przywróciła do linii: 167 dział pancernych, co oznacza, że niektóre działa pancerne były remontowane kilkakrotnie; ЦАMO, f. 46, o. 2404, d. 31 Доклад о боевых действиях БТ и МВ 19 А, b.m. 9 VI 1945 r., k. 287-288. 
Dotychczasowy przebieg walk na Pomorzu sugerował, że nieprzyjaciel będzie starał się utrzymać wielkie ośrodki miejskie, zamieniając je w "twierdze”, tak jak to było w przypadku Torunia, Grudziądza, Wałcza czy Kołobrzegu. Dowództwo 2 F. Biał. starało się uniknąć takiego scenariusza. Kluczowym zadaniem 3 KPanc. Gw. stało zajęcie Słupska, zaś wprowadzenie do walki 1 APanc. Gw. miało uniemożliwić Niemcom stawianie oporu wzdłuż rzeki Łupawy. $3 \mathrm{KPanc}$. Gw. wywiązał się znakomicie z postawionego mu zadania. 8 marca jednostki korpusu wyszły nad brzeg Łupawy, jednak opanowanie Sławna, Słupska i Lęborka nie było równoznaczne z pobiciem nieprzyjaciela. Niemieckie ariergardy stawiały opór na trafnie wytypowanych pozycjach, co umożliwiło wycofanie VII KPanc. z obszaru Równiny Słupskiej bez kontaktu z przeważającym nieprzyjacielem. Marszałek Rokossowski w swoich wspomnieniach nie ukrywał, że nie zdołał powstrzymać Niemców przed wycofaniem się na linię gdyńsko-gdańskiego rejonu umocnionego, jednak w jego opinii wynikało to z następujących przyczyn: „Wycofujący się przeciwnik zdołał mimo wszystko obsadzić wojskami przygotowany już wcześniej gdyńsko-gdański rejon umocniony. Umożliwiły mu to warunki terenowe i wiosenne roztopy. Podczas odwrotu hitlerowcy wysadzali w powietrze i zaminowywali wszelkie drogi, a burząc tamy, zatopili ogromne obszary. Wiele trudności sprawiali nam uciekinierzy. [...] Wszystkie drogi, dróżki i tak już zatarasowanie sprzętem wojskowym porzuconym przez hitlerowców, były zatłoczone bezwolną masą ludzką. Nasze wojska z ogromnym trudem torowały sobie drogę w iście apokaliptycznych warunkach"148. Wprawdzie wymienione przez marsz. Rokossowskiego czynniki miały wpływ na przebieg walk na Pomorzu Gdańskim, jednak niemniej ważna okazała taktyka się zastosowana przez stronę niemiecką.

Doświadczenie z walk na Pomorzu Gdańskim stało się przedmiotem analizy Dowództwa Wojsk Pancernych i Zmechanizowanych (DWPiZ) 19 A. Na zlecenie płk. Nikołaja Majorowa, szefa sztabu DWPiZ 2 F. Biał., sprawozdanie w tej sprawie sporządził ppłk. Aleksiej Gonczarow, szef sztabu DWPiZ $19 \mathrm{~A}^{149}$. Autor dokumentu zwraca uwagę, że: „W pierwszym okresie [6-11/12 marca] nieprzyjaciel pozostawiał ariergardy na obejmowanych rubieżach obrony, tworzonych wzdłuż głównych dróg, ważniejszych osiedli, przeszkodach wodnych i innych miejscach taktycznie dogodnych do obrony [podczas gdy] główne siły dużymi rzutami zbierały się w rejonie GDYNI. [...] Takie metody stosowano w silnie urozmaiconym terenie i masywach leśnych"150. Ogień prowadzono do nadjeżdżających jednostek

${ }^{148}$ K. Rokossowski, Żotnierski..., s. 388.

${ }_{149}$ ЦАМО, f. 46, о. 2404, d. 29, Краткая сводка обобщенного боевого опыта штаба УК БТ и МВ 19 A, b.m. 4 IV 1945 r., k. 405-409.

${ }^{150}$ Ibidem, k. 405. 
sowieckich z punktów ogniowych w oparciu o: „Wybrane wzgórza i nasypy kol[ejowe], znajdujące się w dogodnej lokalizacji z szerokim polem obserwacji obszaru poniżej, zostały obsadzone przez czołgi i działa samobieżne nieprzyjaciela. Na zboczach były wykopane okopy czołgowe, w taki sposób aby [z okopu] wystawała jedynie wieża. Czołg lub działo pancerne znajdujące się w okopie otwierało ogień z dystansu 600-700 metrów, oddając kilka strzałów, a następnie wycofując się za stok wzniesienia na kolejną rubież"151. Działania opóźniające jednostki niemieckie prowadziły również w oparciu o obszary zalesione, gdzie sytuowano stanowiska obronne w następujący sposób: „pozycje ogniowe wybierano na skrajach lasów w sąsiedztwie dróg i prawdopodobnych kierunków działania naszych czołgów. Same czołgi były zamaskowane w odległości 50-100 metrów od pozycji ogniowej. Przy zbliżaniu się naszych [sowieckich] czołgów, nieprzyjacielskie czołgi i działa samobieżne wyjeżdżały $\mathrm{z}$ ukrycia, zajmowały pozycje ogniowe i z odległości 800-1000 metrów prowadziły intensywny ogień, po czym powracały w miejsce ukrycia lub wycofywały się na następną rubież" ${ }^{152}$. Pułkownik Gonczarow zaznaczył przy tym że: „Działa przeciwpancerne nie prowadziły długotrwałych pojedynków ogniowych, tylko ograniczały się do kilku celnych strzałów, po czym następowało przegrupowanie na nową rubież oporu, czasami oddaloną do 2 -ch $\mathrm{km}$. Podczas walk w lasach działa przeciwpancerne ustawiano na skraju polan, co pozwalało im na prowadzenie intensywnego ognia z dystansu 100-300 metrów"153.

Mimo że w taktyce zastosowanej przez stronę niemiecką nie było niczego nowego, to obrona ta okazała się skuteczna wobec sowieckiej broni pancernej ${ }^{154}$.

Wycofane jednostki dowództwo niemieckiej 2 A wykorzystało do obsadzenia fortyfikacji na gdyńskiej i gdańskiej pozycjach umocnionych, formując w ten sposób nową linię oporu. Napotkana obrona przeciwpancerna w postaci stanowisk artylerii przeciwlotniczej, zaadaptowanych do nowych warunków, okazała się zaskoczeniem dla strony sowieckiej. Przebieg bitwy w dniach 13-16 marca wymusił na Sowietach zmianę dotychczasowych planów, czego świadectwem było ponowne wprowadzenie do walki $11 \mathrm{KPanc}$. Gw.

Wbrew założeniu dowództwa 2 F. Biał. walki na Pomorzu Gdańskim przeciągnęły się do początku kwietnia 1945 r., co nie pozostało bez wpływu na termin rozpoczęcia operacji berlińskiej i jej przebieg. Kriegsmarine zdołała przeprowadzić skuteczną operację ewakuacji oficerów i żołnierzy VII KPanc. z Kępy Oksywskiej na Hel, skąd następnie przetransportowano

\footnotetext{
${ }^{151}$ Ibidem, k. 406.

${ }^{152}$ Ibidem.

${ }^{153}$ Ibidem.

${ }^{154}$ Ibidem, k. 407.
} 
ich do Niemiec ${ }^{155}$. Po ewakuacji, na bazie ocalałej kadry, przeprowadzono reorganizację 4 PDGPanc. SS i 7 DPanc. Grupa bojowa skompletowana $\mathrm{z}$ obu dywizji wzięła udział w walkach na terenie Brandenburgii w trakcie operacji berlińskiej. W dniach 26-28 kwietnia żołnierze 7 DPanc. i 8 pgpanc. SS przeprowadzili kontratak na pozycje polskich żołnierzy nad Kanałem Ruppiner ${ }^{156}$.

Działania wojsk sowieckich na Pomorzu Gdańskim zakończyły się zdobyciem portów w Gdańsku i Gdyni oraz zniszczeniem niemieckiej 2 A. Wprawdzie cel operacji został zrealizowany, ale jej przebieg był daleki od oczekiwań dowództwa 2 F. Biał. Początkowo zakładano, że Gdynia wraz z portem zostanie zdobyta już 12 marca. Gdyby tak się stało, klęska niemieckiej 2 A byłaby jeszcze dotkliwsza, a szanse na ewakuację wojsk drogą morską ograniczone. Pomimo skąpych sił strona niemiecka zdołała pokrzyżować zamiar marsz. Rokossowskiego. Wykorzystując charakterystyczne cechy terenu, wojska niemieckie prowadziły walkę tak, aby jak najbardziej oddalić w czasie utratę Gdyni, przy jednoczesnym wyniszczeniu sowieckich wojsk pancernych i piechoty. W konsekwencji twardego oporu nieprzyjaciela dowództwo 2 F. Biał. zostało zmuszone ponownie wykorzystać w bitwie $11 \mathrm{KPanc}$. Gw. Było to niezgodne z pierwotnymi planami Stawki i wiązało się z kolejnymi stratami w sprzęcie pancernym, który starano się zachować przed planowaną operacją berlińską. Wobec zaangażowania kolejnych sił wojska 2 A musiały ulec. Pomimo ostatecznej utraty Pomorza Gdańskiego przemyślana obrona wojsk 2 A spowodowała odsunięcie w czasie bitwy o stolicę III Rzeszy i wydłużała czas trwania II wojny światowej w Europie.

\section{Bibliografia}

\section{Archiwalia}

Centralne Archiwum Wojskowe Wojskowego Biura Historycznego

Zesp. 253: 1 Brygada Pancerna

Centralne Archiwum Ministerstwa Obrony Federacji Rosyjskiej w Podolsku

Фонд 46: Полевое управление 2-го Белорусского фронта

Фонд 299: 1 гвардейская танковая армия

Фонд 500: Трофейный фонд

Фонд 917: 101 гвардейская стрелковая дивизия

Фонд 1024: 27 стрелковая дивизия

Фонд 1068: 10 гвардейская дивизия

Фонд 1284: 102 гвардейская стрелковая дивизия (65 стрелковая дивизия)

Фонд 3067: 3 гвардейская танковая бригада

Фонд 3336: 20 гвардейская механизированная бригада

\footnotetext{
${ }^{155}$ H. Schön, Ostsee '45. Menschen - Schiffe - Schicksale, Stuttgart 1985, s. 357.

156 S. Hamilton, The Oder Front..., s. 247-248, 279.
} 
Фонд 3363: 2 гвардейская мотострелковая бригада

Фонд 3401: 3 гвардейский танковый корпус

Фонд 3440: 1 гвардейская танковая бригада

\section{Źródła wydane}

Русский архив: Великая Отечественная: Ставка Верховного Главнокомандования. Документы и материаль. 1945 год., t. 16 (5-4), red. В. А. Золотариев, Москва 1999.

\section{Wspomnienia}

Katukow M., Pancerny grot, tłum. J. Żarek, Warszawa 1976.

Meisner H., Rok 1945 - Wspomnienia z Pomiłowa [w:] „Mój los był tylko jednym spośród wielu milionów...". Powiat sławieński w roku 1945. Wspomnienia dawnych mieszkańców, red. J. Sroka, Sławno 2008.

Rokossowski K., Żołnierski obowiązek, tłum. F. Czuchrowski, Warszawa 1979.

Бабаджанян А. Х., Дороги победы, Москва 1975.

\section{Opracowania}

Anduła K., 1. Warszawska brygada Pancerna im. Bohaterów Westerplatte na froncie (1943-1945), Warszawa 2015.

Anduła K., Działania bojowe jednostek Armii Czerwonej w bitwie o Kołobrzeg (4-18 marca 1945 r.), „Meritum” 2018, t. X.

Anduła K., Kaszubska pułapka, pancerne boje pod Sławnem, Słupskiem, Lęborkiem i Wejherowem, część 1, „Wojsko i Technika. Historia” 2019, nr 1; część 2, „Wojsko i Technika. Historia” 2019, nr 2.

Anduła K., Pancerne preludium. 45. Brygada Pancerna Gwardii w bitwie o KoŁobrzeg 4-7 marca 1945 roku, „Technika Wojskowa: Historia” 2017, nr 7.

Anduła K., Udział 1 Warszawskiej Brygady Pancernej im. Bohaterów Westerplatte w walkach o Kępę Oksywską (30 marca - 5 kwietnia 1945 r.), „Przegląd Historyczno-Wojskowy" 2012, nr 3 (241).

Barański A., Pogorzelice, 09-10 marca 1945 r. Studium - bitwa czy potyczka?, „Biuletyn Historyczny Lęborskiego Bractwa Historycznego i Muzeum w Lęborku" 2006, nr 29.

Bieszanow W., 1945 - rok zwycięstwa, tłum. G. Palacz, A. Palacz, Warszawa 2013. Боевой состав Советской Армии. Cz. V: (январь-сентябрь 1945 года), red. М. А. Гареев, Москва 1990.

Bölscher B., Hitlers Marine im Landkriegseinsatz: Eine Dokumentation, Norderstedt 2015.

Butter P., Pole walki Prusy: szturm na niemiecki front wschodni 1944-1945, Poznań 2011.

Flisowski Z., Pomorze: reportaż z pola walki, Warszawa 1978.

Gliniecki T., Echa pancernego rajdu. Propaganda wojenna i mity wyzwoleńcze na przykładzie operacji mławsko-elbląskiej Armii Czerwonej w 1945 roku, Gdańsk 2017. 
Gliniecki T., Walki Armii Czerwonej w delcie Wisły (styczeń-maj 1945), Gdynia-Sztutowo 2019.

Gliniecki T., Panto D., Krzywy obraz wojny. Armia Czerwona w Gdańsku i Prusach $w 1945$ r., Gdańsk 2019.

Hamilton S., The Oder Front 1945, t. 2, Solihull 2014.

Historia wielkiej wojny narodowej Związu Radzieckiego 1941-1945 w 6 tomach, t. 5: Zwycięskie zakończenie wojny z hitlerowskimi Niemcami. Klęska imperialistycznej Japonii (1945 r.), red. P. N. Pospiełow, tłum. I. Bukowski, K. Cis, J. Nowacki, Warszawa 1965.

Husemann F., Die guten Glaubens waren: Geschichte der SS-Polizei-Division (4.SS-Polizei-Panzer-Grenadier-Division), t. 2: 1943-1945, Osnabrück 1971.

Jarosz J., Artyleria nadbrzeżna polskiego wybrzeża, Gdynia 2018.

Kardas M., Wybrzeże gdańskie jako pole bitwy w 1945 roku. Na obrzeżach działań wojennych frontu wschodniego [w:] Kresy, granice i pogranicza w historii wojskowej, red. A. Olejko, Oświęcim 2014.

Marsz A. A., Główne cechy geomorfologiczne [w:] Pobrzeże Pomorskie, red. B. Augustowski, Wrocław-Warszawa 1984.

Mitcham jr. S. W., Dywizje strzeleckie i lekkie. Ordre de Bataille, tłum. R. Michulec, Warszawa 2010.

Murawski E., Bój o Pomorze: ostatnie walki obronne na wschodzie, Oświęcim 2017.

Pagel K.-H., Der Landkreis Stolp in Pommern. Zeugnisse seiner deutschen Vergangenheit, Lübeck 1989.

Perzyk B., Baterie przeciwlotnicze niemieckiej marynarki, 1937-1945, cz. II, „Archeologia Wojskowa" 1995, nr 6.

Przytocki K., Warszawska Pancerna: z dziejów 1 Warszawskiej Brygady Pancernej im. Bohaterów Westerplatte 1943-1946, Warszawa 1981.

Rutkowski, T., Adam Bromberg i „encyklopedyści”. Kartka z dziejów inteligencji w PRL, Warszawa 2010.

Schön H., Ostsee '45. Menschen - Schiffe - Schicksale, Stuttgart 1985.

Słownik geograficzno-krajoznawczy Polski, red. M. I. Mileska, Warszawa 1998.

Studium geograficzno-przyrodnicze i ekonomiczne województwa gdańskiego, red. J. Moniak, Gdańsk 1974.

Великая Отечественная война 1941-1945 годов в двенадиати томах, t. 5: Победный финал. Завершающие операции Великой Отечественной войны в Европе. Война с Японией, red. Г. Н. Севостьянов, Москва 2013.

Завьялов А. С., Калядин Т.Е., Восточно-померанская наступательная операция советских войск. Февраль-март 1945 г., Москва 1960.

\section{Strony internetowe:}

https://forum.axishistory.com/viewtopic.php?t=89403 (dostęp 1 XII 2018 r.). http://tankfront.ru/ussr/mk/gvmk08.html (dostęp 18 X 2018 r.).

http://www.fortyfikacje.eksploracja.pl/fr_markowiec.htm (dostęp 22 III 2018 r.). http://www.nevskye.narod.ru/2_nevskyh/bykovsky.htm (dostęp 25 X 2018 r.). 


\section{STRESZCZENIE}

\section{Kamil Anduła, Bitwa w Pradolinie Redy-teby. Działania bojowe sowieckich wojsk pancernych na kierunku Gdyni (6-16 marca 1945 r.)}

Historia bojów na Pomorzu Gdańskim w 1945 r. została ukształtowana przez historiografię sowiecką. Celem artykułu jest przedstawienie działań operacyjnych sowieckiej broni pancernej prowadzonych na przedpolu Gdyni na podstawie materiału źródłowego z zasobu Centralnego Archiwum Ministerstwa Obrony Federacji Rosyjskiej.

Duże znaczenie dla przebiegu walk o Gdynię miała bitwa w Pradolinie Redy-Łeby. 6 marca 1945 r. wojska 2 Frontu Białoruskiego rozpoczęły ofensywę, skutkiem której było szybkie opanowanie Sławna, Słupska i Lęborka. Pomimo dużej szybkości natarcia wojska sowieckie nie zdołały zniszczyć sił niemieckich. W oparciu o system stanowisk obrony przeciwlotniczej jednostki niemieckiej 2 Armii zdołały zatrzymać sowieckie natarcie pod Wejherowem i Rumią. Ważny wpływ na przebieg walk miało charakterystyczne dla Pomorza Gdańskiego ukształtowanie terenu.

Przebieg i skutki bitwy w Pradolinie Redy-Łeby wymusiły na dowództwie 2 Frontu Białoruskiego zmianę przyjętych założeń. Konsekwencją sowieckiego niepowodzenia w Pradolinie Redy-Łeby był rozkaz marszałka Konstantego Rokossowskiego o skierowaniu do walki o Gdynię dodatkowych sił, co wpłynęło na przebieg działań wojennych. Ze względów propagandowych w bitwę w Pradolinie Redy-Łeby została zaangażowana 1 Brygada Pancerna im. Bohaterów Westerplatte z szeregów ludowego Wojska Polskiego, co zostało okupione dużymi stratami.

Słowa kluczowe: 2 Front Białoruski, broń pancerna, ludowe Wojsko Polskie, Pradolina Redy-Łeby, Rumia, Konstanty Rokossowski, Wejherowo

\section{SUMMARY}

\section{Kamil Anduła, Battle in Reda-Łeba Urstromtal Valley. Combat Operations of Soviet Armoured Forces towards Gdynia (6-16 March 1945)}

The history of battles in Gdańsk Pomerania in 1945 was shaped by Soviet historiography. Relying on the source material from the Central Archives of the Ministry of Defence of the Russian Federation, the article presents the operational activities of Soviet armoured units in the outskirts of Gdynia.

Of great importance for the course of the fights for Gdynia was the battle in Reda-Łeba Glacial Valley. On March 6, 1945, the units of the 2nd Belorussian Front began a rapid offensive and quickly seized Sławno, Słupsk and Lębork. Despite the high speed of the offensive, the Soviets did not manage to destroy the retreating German forces. Basing on a system of anti-aircraft defense posts, German 2nd Army units managed to stop the Soviet attack at Wejherowo and Rumia. The thopographical characteristics of Gdańsk Pomerania had a strong influence on the fights. 
The course and effects of the battle in the Reda-Łeba Glacial Valley forced the command of the 2nd Belorussian Front to reconsider the previous operational assumptions. As consequence of the Soviet failure in the Reda-€eba Glacial Valley, Marshal Konstantin Rokossovsky ordered to send additional forces to fight for Gdynia. For the sake of propaganda, the Polish 1st Armoured Brigade of the Heroes of Westerplatte was also engaged in the battle, which came at a price of heavy casualties.

Keywords: 2nd Belorussian Front, armoured units, Polish People's Army, Reda-Łeba Urstromtal Valley, Rumia, Konstantin Rokossovsky, Wejherowo

\section{АННОТАЦИЯ \\ Камиль Андула, Битва в Прадолине Реды-Лебы. Боевые действия советских бронетанковых войск в направлении Гдыни (6-16 марта 1945 г.)}

Историю сражений в Гданьском Поморье 1945 г. упорядочила советская историография. Цель данной статьи - представить оперативную деятельность советской бронетехники в окрестностях Гдыни на основе материалов из Центрального архива Министерства обороны Российской Федерации.

Сражение в Прадолине Реды-Лебы имело большое значение для хода боев за Гдыню. 6 марта 1945 г. войска 2-го Белорусского фронта перешли в наступление, в результате которого были быстро взяты Славно, Слупск и Лемборк. Несмотря на высокую скорость атаки, советским войскам не удалось уничтожить отступающих немцев. На основе системы противовоздушной обороны частям 2-й немецкой армии удалось остановить наступление советских войск под Вейхерово и Румей. Характер территории Гданьской Померании оказал большое влияние на ход боев. Ход и последствия боя в Прадолине Реды-Лебы заставили командование 2-го Белорусского фронта изменить принятую линию поведения.

Следствием неудачи советских войск в Прадолине Реды-Лебы стал приказ маршала Константина Рокоссовского о направлении дополнительных сил для борьбы за Гдыню. Из пропагандистских соображений в сражении в Прадолине Реда-Леба приняла участие 1-я бронетанковая бригада им. Героев Вестерплатте, сформированная из рядов Польской Народной Армии, что привело к большим потерям.

Ключевые слова: 2-й Белорусский фронт, бронетанковые войска, народное Войско Польское, Прадолина Реды-Лебы, Румя, Константин Рокоссовский, Вейхерово 